\title{
REVISION OF THE RED LIST STATUS OF HUNGARIAN BRYOPHYTES 1. NEW OCCURRENCES OF SPECIES PREVIOUSLY THOUGHT TO BE REGIONALLY EXTINCT OR WITHOUT RECENT DATA
}

\author{
Peter Erzberge R ${ }^{1 *}$, Csaba Németh ${ }^{2}$, Beáta PapP ${ }^{3}$, \\ Attila MesterházY ${ }^{4}$, János CsiKY ${ }^{5}$ and Kornél BARÁth ${ }^{6}$ \\ ${ }^{1}$ Belziger Str.37,D-10823 Berlin, Germany; *erzberger.peter@gmail.com \\ ${ }^{2}$ Department of Botany and Soroksár Botanical Garden, Faculty of Horticultural Science, \\ Corvinus University of Budapest, H-1118 Budapest, Villányi út 29-43, Hungary \\ ${ }^{3}$ Department of Botany, Hungarian Natural History Museum, H-1476 Budapest, Pf. 222, Hungary \\ ${ }^{4} \mathrm{H}-9500$ Celldömölk, Hunyadi u. 55, Hungary \\ ${ }^{5}$ University of Pécs, Faculty of Sciences, Institute of Biology, Department of Ecology, \\ H-7624 Pécs, Ifjúság u. 6, Hungary \\ ${ }^{6}$ Institute of Biology, University of West Hungary, \\ H-9700 Szombathely, Károlyi Gáspár tér 4, Hungary
}

Erzberger, P., Németh, Cs., Papp, B., Mesterházy, A., Csiky, J. \& Baráth, K. (2015): Revision of the red list status of Hungarian bryophytes 1 . New occurrences of species previously thought to be regionally extinct or without recent data. - Studia bot. hung. 46(2): 15-53.

\begin{abstract}
For 37 species that have been without recent data and therefore listed in the categories regionally extinct $(\mathrm{RE})$ and data deficient (DD, DD-va), new occurrences have been detected. These are documented with precise localities, date of collection, collectors, herbarium specimens, associated bryophytes, and taxonomic annotations where appropriate. Some are also illustrated by photographs, and for three of them we include distribution maps. According to the present state of knowledge and IUCN criteria, of these 37 species 10 are critically endangered, 14 are endangered, 2 are vulnerable and 5 are near threatened. In spite of the new occurrences, 6 species are rated data deficient (DD).
\end{abstract}

Key words: IUCN categories, liverworts, mosses, threatened taxa

\section{INTRODUCTION}

Checklists and red lists usually are outdated at the time when they appear in print. The latest red list (PAPP et al. 2010) is no exception. Since its publication about 20 taxa new to the Hungarian bryoflora have turned up, and some have to be excluded, but these changes to the checklist will be dealt with elsewhere. Here we focus on necessary changes in red-list status due to new records of long-known members of the Hungarian flora. In particular, bryofloristic activity related to systematic grid cell recording (Erzberger 2012, Erzberger and Németh 
2013), but also other projects, have produced numerous remarkable records of rare and endangered taxa. Recent revision of collections of the first author from the past two decades has also furnished some contributions.

Whereas the red list category "data deficient (DD)" was used in PAPP et al. (2010) only for taxa without recent data, we use this category in a different sense that follows more closely the definition given by IUCN (2014), i.e. we use this category also in cases where recent data are available, but insufficient for assigning a threat category. In this way, some of the taxa that were without recent data according to PAPP et al. (2010), are at present still rated DD although new occurrences have been found. In order to distinguish our rating from the label DD used in PAPP et al. (2010), we add the tag "IUCN", indicating that we explicitly refer to the use proposed by IUCN (2014). However, for most taxa with new occurrences, proper threat categories could be assigned. We give details of the records and propose an amended red-list status.

For most rare bryophytes it is essential to know their ecological needs, where and under which conditions they grow, in order to find new occurrences. We therefore also give some details of their substrate and associated bryophytes, in the hope that this may lead to further discoveries. Some annotations on characteristic features and photographs might also be effective in this way.

In papers to follow in this series, those species red-listed in PAPP et al. (2010) as critically endangered (CR), endangered (EN), and vulnerable (VU), for which new data are available, will be treated in a similar way. It is the purpose of these papers to communicate the distributional data which will lead to a re-evaluation of the red list status of Hungarian bryophytes, since in the light of the new occurrences a more precise assessment is possible. In many cases this will imply the lowering of the red list category of species presently thought to be threatened. As a final synthesis of this series, a new edition of the checklist and red list is planned.

Three of the species treated here (Brachythecium geheebii, Riccia frostii, $R$. huebeneriana) are protected by law in Hungary (MK 2012).

For the species of this compilation that are red-listed on a European scale (ECCB 1995), we include their status. A new European red list has not been published, but in a checklist of all bryophytes of Europe, candidates for the new red list are labelled (HoDGETTS 2015). We also add this label where appropriate.

\section{MATERIAL AND METHODS}

Field work was carried out in the years 2012-2015. However, some earlier collections of the first author which have been revised in recent years, are also considered. Geographical coordinates were determined with a Garmin eTrex Legend GPS; altitudinal data are approximate. Supplementary photographs were taken by the second author. 
In assigning threat categories, we closely follow the methods of the previous red list (PAPP et al. 2010) except in the case of DD, as explained in the Introduction. Thus, using criterion B (IUCN 2014), the number of presently known occurrences is evaluated as in PAPP et al. (2010): 1 (CR), <5 (EN), <10 (VU). Here we adopt the interpretation of HALLINGBÄCK et al. (1998) for the term "location" as used in IUCN (2014), i.e. we count numbers of localities or sites.

In order to give accurate information about the number of earlier records, in most cases herbarium specimens would have had to be revised. This was beyond the scope of the present work. Thus, apart from taxa that have already been subject to revision (Bryum: ERzBerger and SCHRÖDER 2013, Campylopus pyriformis: Csiky et al. 2014, Conardia compacta: Németh 2011, Poblia: Erzberger 2005, Seligeria: Gos and OCHYRA 1994), for earlier occurrences mostly Boros (1968) and ORBÁn and VAJdA (1983) were consulted. According to the information in these accounts, for some rare species the actual number of records could be inferred (Brachythecium capillaceum, Bryum funckii, B. intermedium, Campylopus pyriformis, Conardia compacta, Jungermannia atrovirens, Leiocolea badensis, Philonotis marchica, Poblia annotina, P. proligera, Racomitrium affine, Riccia subbifurca, Seligeria campylopoda, S. trifaria var. longifolia, Syntrichia caninervis var. gypsophila), whereas for others only the number of grid cells or bryogeographic regions, or for generally distributed species even less precise data could be obtained.

Nomenclature of bryophytes follows ERZBERGER and PAPP (2004) and PAPP et al. (2010) in most instances, exceptions are species that are missing from these checklists, e.g. Bryum lonchocaulon Müll. Hal., where ERZBERGER and SCHRÖDER (2013) is followed, Bruchia flexuosa (Schwägr.) Müll. Hal. and Syntrichia Brid. where Hill et al. (2006) is followed.

Abbreviation of herbaria: $\mathrm{BP}=$ Hungarian Natural History Museum; Budapest; EGR = herbarium of Eszterházy Károly College in Eger; B-Erzberger = Botanical Garden and Botanical Museum, Berlin-Dahlem (collection of P. Erzberger); $\mathrm{HCsN}=$ private herbarium of Csaba Németh, JPU = herbarium of Janus Pannonius University, Pécs

Abbreviation of red list categories (for details of definition, see PAPP et al. 2010): $\mathrm{RE}=$ regionally extinct, $\mathrm{CR}=$ critically endangered, $\mathrm{EN}=$ endangered, $\mathrm{VU}=$ vulnerable, $\mathrm{NT}=$ near threatened, $\mathrm{DD}=$ data deficient (without recent data), DD-va = data deficient vanished (taxa with old records that had not been re-confirmed in spite of searching the old sites), $\mathrm{DD}(\mathrm{IUCN})=$ data deficient in the sense of IUCN (2014) (see Introduction).

Abbreviation of red list categories according to ECCB (1995): CR = critically endangered, $\mathrm{E}=$ endangered, $\mathrm{R}=$ rare, $\mathrm{RT}=$ regionally threatened, $\mathrm{K}=$ insufficiently known, $\mathrm{V}=$ vulnerable. 


\section{RESULTS AND DISCUSSION}

\section{Taxa formerly regionally extinct}

\section{Ulota hutchinsiae (Sm.) Hammar}

(Fig. 1)

Amended red list status: CR. Candidate for new European red list (HodgetTs 2015).

Balaton Uplands - [9070.3] Veszprém county, upper Lesence-stream Valley near Uzsa (Sümeg), on sandstone conglomerate outcrops (Kisbéri Kavics Formáció) in deciduous forest, $46.93450^{\circ} \mathrm{N}, 17.34328^{\circ} \mathrm{E}, 200 \mathrm{~m}$; leg. Cs. Németh and P. Erzberger, 29.06.2013, B-Erzberger 16490, HCsN 4971, BP 186738; and $46.93367^{\circ} \mathrm{N}, 17.34294^{\circ} \mathrm{E}, 200 \mathrm{~m}$; leg. Cs. Németh and P. Erzberger, 07.06.2014 (Fig. 1), B-Erzberger 17989, HCsN 5596. Associated bryophytes: Grimmia trichophylla Grev., Hedwigia ciliata (Hedw.) Beauv. var. ciliata.

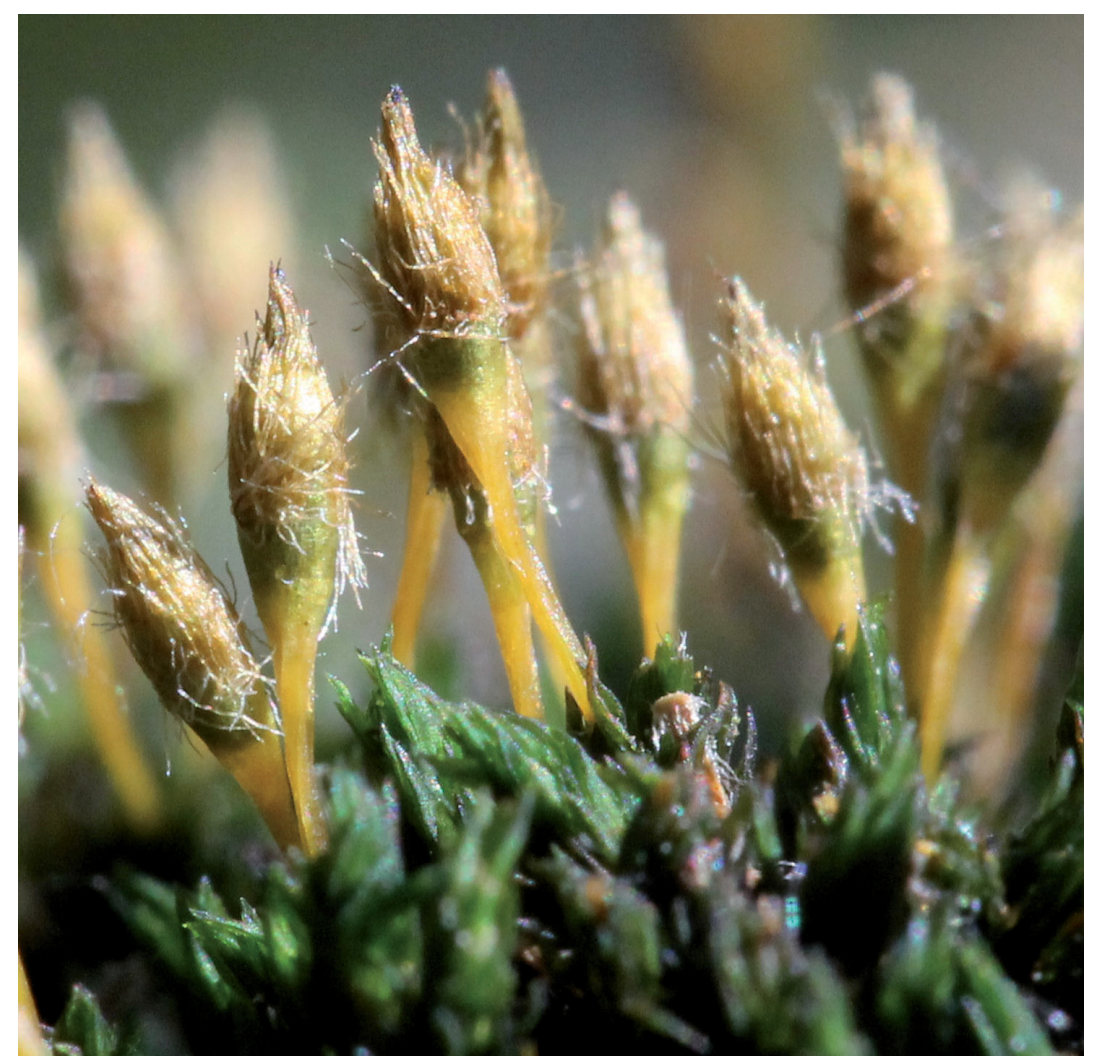

Fig. 1. Ulota hutchinsiae, Balaton Uplands, Sümeg-Uzsa, Lesence Valley (photo: Cs. Németh, 07.06.2014 [9070.3]). 
Ulota hutchinsiae was first reported in Hungary from the Mecsek Mts (Misina) by LATzel (1934). Boros (1953) listed two occurrences of the species, Buda Mts and Mecsek Mts, noting in brackets "According to Igmándy and Latzel, respectively". Consequently, he had probably never seen the corresponding voucher specimens. Later Boros (1968) as well as OrBÁN and VAJDA (1983) also cited these localities. RAJCZY (1990) in the first red list of Hungarian bryophytes marked $U$. hutchinsise with the RE category. During the preparation of the Hungarian checklist, ERzBERGER and PAPP (2004) did not find any specimens of $U$. hutchinsiae neither in BP nor in EGR, the two largest bryophyte collections of the country. Based on the lack of voucher material the species remained in the RE category also in the new red list (PAPP et al. 2010).

In habit it is superficially resembling Orthotrichum anomalum Hedw., with exserted capsules and growing on rock, the leaves are not crisped as in other Ulota species, but are distinguished, among others, by colonising siliceous (rather than calcareous) rock, a much more hairy calyptra, and phaneropore stomata.

Taxa formerly vanished (DD-va)

\section{Brachythecium gebeebii Milde}

Amended red list status: CR; also protected by law (MK 2012). Candidate for new European red list (HodgetTs 2015); ECCB (1995): R.

Börzsöny Mts - [8079.2] Pest county, Kopolya-kövek near Kemence-Királyháza, andesite boulder scree in deciduous forest above Rakottyás Valley, $47.96300^{\circ} \mathrm{N}, 18.94931^{\circ} \mathrm{E}, 700 \mathrm{~m}$; leg. Cs. Németh, B. Papp and P. Erzberger, 20.06.2014, B-Erzberger 18173, HCsN 5661. Associated bryophytes: Homalothecium philippeanum (Spruce) Schimp., Plagiothecium denticulatum (Hedw.) Schimp., Taxiphyllum wissgrillii (Garov.) Wijk et Margad.

There are old data from the Zemplén Mts, Visegrád Mts, and also from the Börzsöny Mts (Hangyás-bérc, Bagolybükki-völgy: Boros 1968), but not from the locality where it was found recently.

This plant looks similar to a small Homalothecium philippeanum; from which it can be distinguished by the stouter costa and slightly wider laminal cells (6-10 $\mu \mathrm{m}$ versus $5-7 \mu \mathrm{m}$ in Homalothecium).

\section{Fontinalis hypnoides Hartm.}

Amended red list status: CR. Candidate for new European red list (HoDGETTS 2015).

Tapolca Basin - [9170.2] Veszprém county, in thermal water of lake Malom-tó at Tapolca, $46.88108^{\circ} \mathrm{N}, 17.44106^{\circ} \mathrm{E}, 125 \mathrm{~m}$; leg. A. Mesterházy and Cs. Németh, 15.11.2014, HCsN 6404, 6405; leg. B. Papp, Cs. Németh, P. Erzberger and A. Kovács, 24.10.2015, B-Erzberger 20954. Associated bryophytes: Fontinalis antipyretica Hedw., Platyhypnidium riparioides (Hedw.) Dixon. 
This occurrence was already mentioned in Boros (1968) and documented by many exsiccata. There are also old reports from other thermal waters (Miskolc, Tata), from Lake Balaton and from a backwater of the river Dráva (Boros 1968).

The leaves of $F$. antipyretica are usually sharply keeled, whereas they are not keeled, plane or very slightly concave in F. hypnoides. However, F. antipyretica can also produce leaves without keel, but usually on the same stem older leaves that are more typical can be found.

Isopterygiopsis pulchella (Hedw.) Z. Iwats.

Amended red list status: VU.

Bakony Mts - [8673.3] Bakonyoszlop, Ördög-árok (NÉmETH 2011). Associated bryophytes: Conardia compacta, Seligeria pusilla (Hedw.) Bruch et Schimp., Eucladium verticillatum (With.) Bruch et Schimp., Cololejeunea rossettiana (C. Massal.) Schiffn., Gymnostomum calcareum Nees et Hornsch. - [8673.3] Bakonybél, Nagy-Som-hegy (Nagy-Pénz-lik cave) (Boros 1968, NÉMETH 2011). Associated bryophytes: Taxiphyllum wissgrillii, Fissidens gracilifolius Brugg.-Nann. et Nyholm. - [8772.1] Bakonybél, Száraz-Gerence-völgy (Pörgöl cave) (NÉMEtr 2011). - [8772.4] Bakonybél, Kertes-kői-szurdok (Oltár-kő) (NÉmETH 2011). - Bükk Mts - [7989.3] Borsod-AbaújZemplén county, Bükk Mts, around Balla cave at Répáshuta, on limestone rocks, $48.04711^{\circ} \mathrm{N}$, 20.53125 E, 530 m; leg. B. Papp, 28.08.2012, BP 186224. - Vértes Mts - [8576.2] Vértesboglár, Fáni-völgyi-odú (NÉmetr 2011). Associated bryophyte: Conardia compacta (Müll. Hal.) H. Rob.

Boros (1968) reported this species from several caves in the Bükk Mts, Pilis Mts, Mt Naszály, Bakony Mts and Mecsek Mts. At present, 6 occurrences of the species are known (one confirmation of Boros 1968's record, 4 recently published and one additional above), thus the modification of the species' red list status was required.

In appearance this moss greatly resembles Orthothecium intricatum (Hartm.) Schimp., occasionally growing in similar habitats. Leaves of I. pulchella, however, are erectopatent, held away from the stem at a slightly greater angle $\left(c a 45^{\circ}\right)$ than those of $O$. intricatum $\left(\mathrm{ca} 30^{\circ}\right)$.

\section{Riccardia chamedryfolia (With.) Grolle}

Amended red list status: CR.

Vendvidék - [9163.1] Vas county, stream valley north of Hegyes Hill near Felsőszölnök, on rotten wood in deciduous forest, very sparse, $46.86217^{\circ} \mathrm{N}, 16.16917^{\circ} \mathrm{E}, 340 \mathrm{~m}$; leg. P. Erzberger, 17.07.2014, B-Erzberger 18496 (det. P. Erzberger, conf. W. Schröder). Associated bryophyte: Riccardia palmata (Hedw.) Carruth.

Boros (1968) reported this rare species from 4 regions, among them from the Vendvidék.

Riccardia chamedryfolia is best distinguished from the somewhat similar $R$. multifida (L.) Gray by the presence of oil bodies in nearly all marginal and epidermal cells (this requires, however, microscopical examination of fresh material, which was possible with the above-mentioned collection). 
Previously data deficient taxa

(with old records that had not been re-confirmed till 2010)

Brachythecium capillaceum (F. Weber et D. Mohr) Giacom.

Amended red list status: $\mathrm{DD}(\mathrm{IUCN})$. Candidate for new European red list (HodgetTs 2015).

Bakony Mts - [8775.4] Fejér county, Szenes-Horog near Csór, narrow valley in dolomite hills, at the base of Quercus cerris L. tree, $47.22794^{\circ} \mathrm{N}, 18.25483^{\circ} \mathrm{E}, 240 \mathrm{~m}$; leg. Cs. Németh and P. Erzberger, 15.03.2015, B-Erzberger 19422, HCsN 6520 (det. W. Schröder 25.06.2015). Associated bryophyte: Amblystegium subtile (Hedw.) Schimp. - Bükk Mts - [7989.1] Borsod-Abaúj-Zemplén county, Svédfenyves near Jávorkút south of Ómassa, old spruce plantation, $48.09892^{\circ} \mathrm{N}, 20.53114^{\circ}$ E, 690 m; leg. P. Erzberger, B. Papp and P. Ódor, 21.08.1999, B-Erzberger 5783 (det. L. Meinunger and W. Schröder 15.03.2015). Associated bryophyte: Amblystegium serpens (Hedw.) Schimp.

Boros (1968) mentioned one occurrence in the Börzsöny Mts, OrBÁN and VAJdA (1983) in addition from the Visegrád Mts (as B. salebrosum var. capillaceum), but revision of the specimens would be desirable.

This species is characterised by a conspicuous yellowish-green colour, an autoicous sex condition, often producing sporophytes with a smooth seta, less robust than B. salebrosum (F. Weber et D. Mohr) Schimp., from which it also differs in a nearly erect capsule that is gradually narrowed to the seta, whereas $B$. salebrosum has curved to horizontal capsules. Alar cells are dark in B. capillaceum, and hyaline in $B$. salebrosum. B. capillaceum is presumably more widely distributed but under-recorded. Therefore we assign the category $\mathrm{DD}(\mathrm{IUCN})$.

\section{Bryum creberrimum Taylor}

Amended red list status: EN.

In addition to a recent record ([8782.1] Csévharaszt, 2013) published in ERZBERGER and SCHRÖDER (2013: note added in proof; associated bryophytes: Rhynchostegium megapolitanum (F. Weber et D. Mohr) Schimp., Encalypta vulgaris Hedw.), a new occurrence was found.

Bakony Mts - [9069.4] Zala county, at the bottom of an abandoned basalt quarry near Sümegprága, on moist soil near a temporary pond, $46.92964^{\circ} \mathrm{N}, 17.28975^{\circ} \mathrm{E}, 265 \mathrm{~m}$; leg. Cs. Németh, P. Erzberger, B. Papp and A. Kovács, 23.10.2015, B-Erzberger 20920/A (det. P. Erzberger).

Old occurrences are documented from 11 grid cells in ERZBERGER and SCHRÖDER (2013), but not from this region.

This species is readily identified when well grown by its synoicous sexual condition, small spore size $(12-16 \mu \mathrm{m})$, cylindric capsules with appendiculate endostome cilia and narrow leaves with longly excurrent costa. From B. bimum (Schreb.) Turner, with which it shares the synoicous inflorescence, it is distin- 
guished by its narrower leaves (more ovate in $B$. bimum), narrower laminal cells (10-15 $\mu \mathrm{m}$ vs. $15-20 \mu \mathrm{m})$ and an often longer, more cylindric capsule.

\section{Bryum funckii Schwägr.}

(Fig. 2)

Amended red list status: CR. Candidate for new European red list (HodGETTS 2015).

In addition to the recent record ([8276.3] Neszmély, 1996) published in ERZBERGER and SCHRÖDER (2013), where the species could not be re-found despite a search in 2013, the following occurrence was found.

Bükk Mts - [7989.2] Borsod-Abaúj-Zemplén county, Szinva Valley near Miskolc-Lillafüred, opposite Kerek-hegy, at the road to Hollóstetö, open steep slope with limestone scree, $48.08553^{\circ} \mathrm{N}$, $20.61503^{\circ} \mathrm{E}, 404 \mathrm{~m}$; leg. Cs. Németh accompanied by B. Papp, E. Szurdoki and P. Erzberger, 17.03.2015 (Fig. 2), B-Erzberger 19440, HCsN 6529 (det. Cs. Németh and P. Erzberger, conf. W. Schröder). Associated bryophytes: Mannia triandra (Scop.) Grolle, Pottia intermedia (Turner) Fürnr.

At Neszmély, the species was found in a loess cliff, which represents an instable habitat, with a high risk of extinction. At the new site in the Bükk Mts, the population was very small and scattered, which also implies a relatively high risk of extinc-

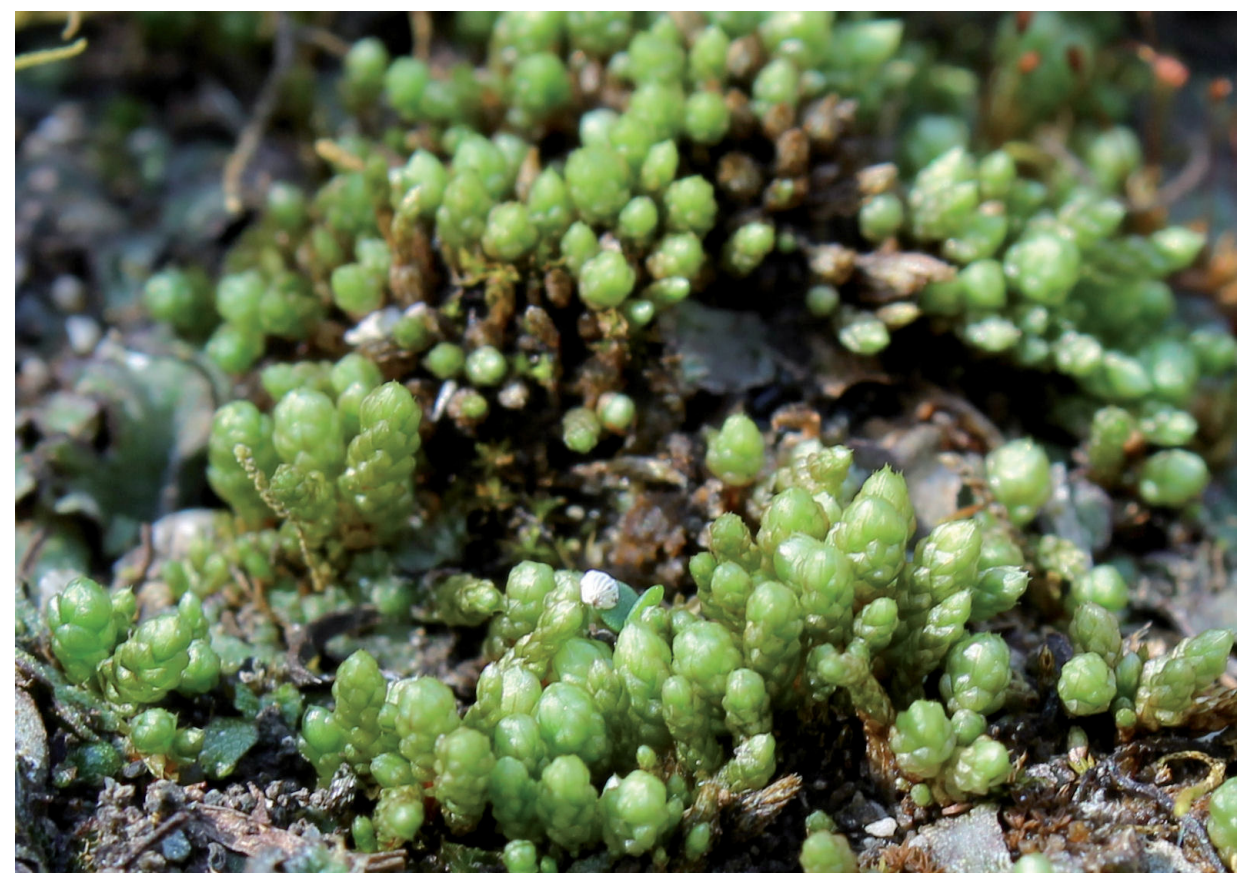

Fig. 2. Bryum funckii, Bükk Mts, Miskolc-Lillafüred, Szinva Valley (photo: Cs. Németh, 17.03.2015 [7989.2]). 
tion. Since the species was not re-found at the first mentioned site, the Bükk population possibly is the only existing one. Therefore, we propose CR as red list status.

\section{Bryum gemmilucens $\mathrm{R}$. Wilczek et Demaret}

Amended red list status: EN.

Two recent records ([8278.3] Tokod, 2008; [8592.2] Hortobágy, 2003) published in ERzberger and SCHRöder (2013). A duplicate gathering from Mt Gete, Tokod, turned up during revision in the specimen B-Erzberger 12775. Also collected at Hortobágy in 2014.

Tiszántúl - [8592.2] Hajdú-Bihar county, Angyalháza at Nádudvar, saline grassland, 47.49094 N, $21.14456^{\circ}$ E, 85 m; leg. B. Papp, 15.04.2014, BP 189279. Associated bryophytes at Hortobágy: Phascum cuspidatum Hedw. var. cuspidatum, Bryum argenteum Hedw.; at Tokod: Phascum curvicolle Hedw., Ph. cuspidatum var. cuspidatum, Pottia mutica Venturi, Acaulon triquetrum (Spruce) Müll. Hal.

\section{Bryum intermedium (Brid.) Blandow}

Amended red list status: $\mathrm{DD}(\mathrm{IUCN})$. Candidate for new European red list (HodgetTs 2015).

Two old occurrences from adjoining sites are documented in ERZBERGER and SCHRÖDER (2013), in addition there is only one recent record ([9182.2] Fülöpháza, 2013) published in ERZBERGER and SCHRÖDER (2013: note added in proof). Associated bryophyte: Drepanocladus aduncus (Hedw.) Warnst.

This species requires ripe sporophytes for identification and therefore is probably under-recorded.

\section{Bryum mildeanum Jur.}

Amended red list status: EN. Candidate for new European red list (HoDGETTS 2015).

Six old occurrences and three "recent" records, two of which date from 1975 ([8292.4] Újszentmargita, 1975; [8591.2] Nagyiván, 1975; [8379.2] Pomáz, 2013), were published in Erzberger and SCHröDER (2013). Associated bryophytes at Pomáz: Grimmia ovalis (Hedw.) Lindb., Pleuridium subulatum (Hedw.) Rabenh., Pleurochaete squarrosa (Brid.) Lindb.

\section{Bryum pallescens Schleich.}

Amended red list status: EN.

Of four recent records of the $B$. pallescens group (including $B$. pallescens, $B$. creberrimum and $B$. lonchocaulon Müll. Hal.) published in ERzBERGER and SCHRÖDER (2013), some possibly refer to B. pallescens s. str., although due to 
the difficulties of establishing sexual condition this could not unambiguously be demonstrated ([8684.3] Tápióbicske, 1997; [9280.2] Fülöpszállás, 1998; [9280.4] Állampuszta, 1995; [9372.1] Gugy, 2011).

In addition to occurrences from 12 grid cells published in ERZBERGER and SCHRÖDER (2013), three additional records of B. pallescens s. str. (autoicous) were found recently, one (from Zala county) representing an interesting, possibly undescribed form of the species, where male inflorescences are situated between the female ones (observed by W. Schröder).

Bakony Mts - [8874.3] Veszprém county, dolomite hill SW of the village Hajmáskér, on soil between rock outcrops near planted Pinus nigra J. F. Arnold, $47.13500^{\circ} \mathrm{N}, 18.00142^{\circ} \mathrm{E}, 190 \mathrm{~m}$; leg. P. Erzberger and Cs. Németh, 07.03.2015, B-Erzberger 19266, HCsN 6507 (det. W. Schröder). Associated bryophytes: Bryum capillare Hedw., B. torquescens Bruch et Schimp. - Bükk Mts - [7889.4] Borsod-Abaúj-Zemplén county, near the entrance of Anna cave near Miskolc (Lillafüred), in the fissure of an artificial limestone wall, $48.10469^{\circ} \mathrm{N}, 20.62436^{\circ} \mathrm{E}, 300 \mathrm{~m}$; leg. Cs. Németh and P. Erzberger, 05.08.2015, HCsN 7224 (det. W. Schröder). Associated bryophyte: Bryum capillare. - Zala - [9567.2] Zala county, between Sormás and Nagykanizsa, "Gödörvény", near road, sand dry grassland, $46.46025^{\circ} \mathrm{N}, 16.93042^{\circ} \mathrm{E}, 160 \mathrm{~m}$; leg. P. Erzberger and T. Pócs guided by M. Óvári, 25.09 .2014 , B-Erzberger 18886 (det. P. Erzberger, conf. W. Schröder). Associated bryophytes: Brachythecium albicans (Hedw.) Schimp., Bryum caespiticium Hedw., Syntrichia ruralis (Hedw.) F. Weber et D. Mohr.

Collected in probably the same location in 1948 by Á. Károlyi (ErzBERgER and SCHRÖDER 2013).

\section{Bryum turbinatum (Hedw.) Turner}

Amended red list status: EN. Candidate for new European red list (HoDGETTS 2015).

Old occurrences form 11 grid cells and two recent records ([8873.4] Gyulafirátót, 2012; [9170.2] Tapolca, 2001) were published in ERZBERGER and SCHRÖDER (2013). One of them was recently confirmed independently.

Balaton Uplands - [9170.2] Veszprém county, near the pond Malom-tó at Tapolca, on rocks of small waterfall at the watermill, $46.88133^{\circ} \mathrm{N}, 17.44100^{\circ} \mathrm{E}, 125 \mathrm{~m}$; leg. A. Mesterházy and Cs. Németh, 15.11.2014, HCsN 6410 (det. P. Erzberger, conf. W. Schröder).

In spite of the scarceness of data, we consider this species to be endangered, since its wetland habitats are under much pressure and in danger of deterioration.

\section{Campylopus pyriformis (Schultz) Brid.}

\section{(Fig. 3)}

Amended red list status: EN.

Erzberger and PAPP (2004) mention a single record ([0071.2] Darány, 1923), but did not give specimen details, because then no specimen could be found. In the meantime, two specimens referring to the single record have been located in BP, but only one represents C. pyriformis: Comit. Somogy. In alnetis paludosis 
Nagyberek prope Darány 24.07.1923 leg. Á. Boros BP 101574. A second specimen (BP 191577) from the same site, collected also by Boros 08.08.1927 contains only Dicranella heteromalla (Hedw.) Schimp. and Ceratodon purpureus (Hedw.) Brid. (rev. P. Erzberger, unpublished). Recently, the species was re-found at this site.

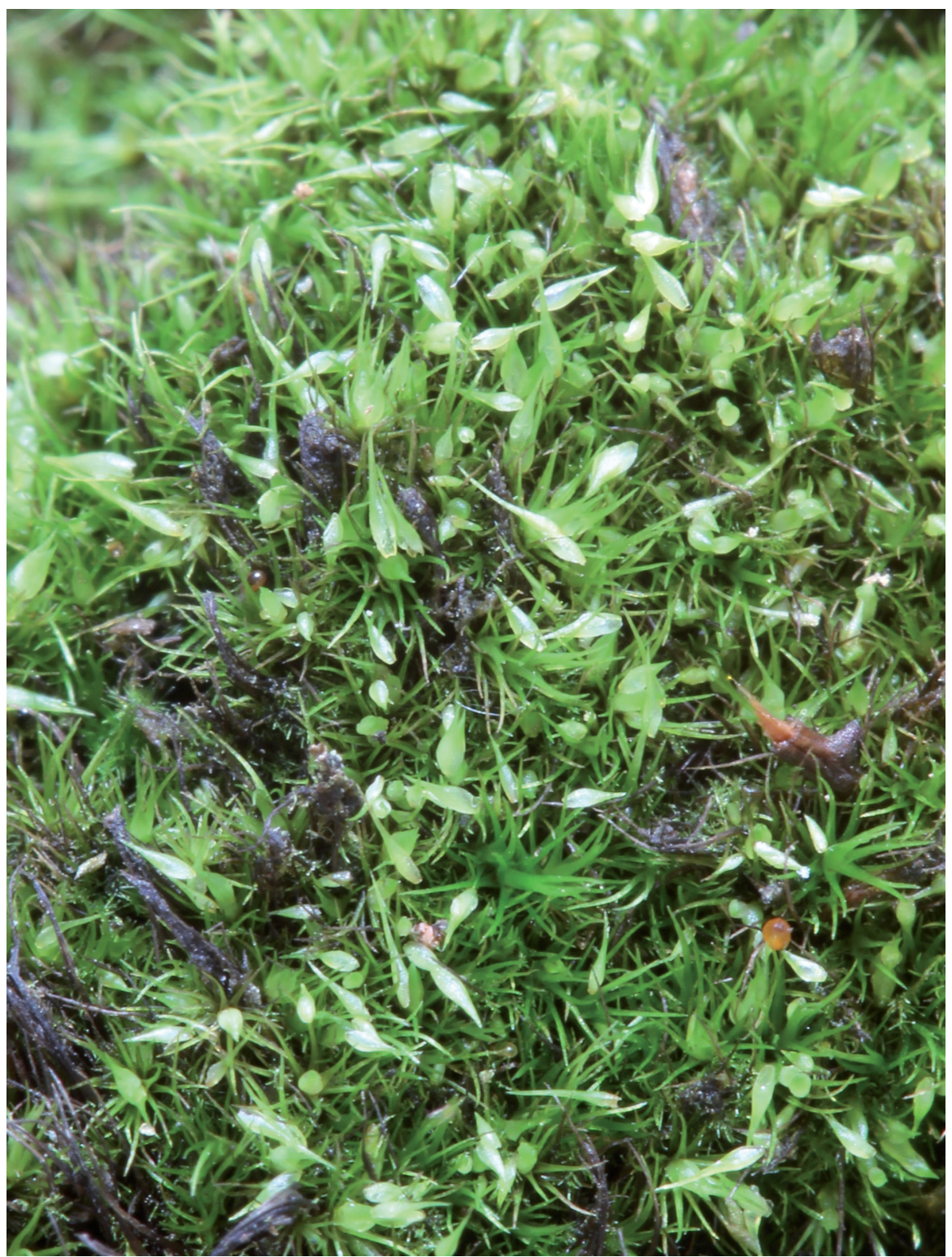

Fig. 3. Campylopus pyriformis, Dráva-sík, Darány, Nagyberek (photo: Cs. Németh, 30.09.2015 [0071.1]). 
Dráva-sík - [0071.1] Somogy county, Nagyberek near Darány, moorland, $45.99478^{\circ} \mathrm{N}$, 17.55714 ${ }^{\circ}$ E, 130 m; leg. P. Erzberger, Cs. Németh and A. Mesterházy, 30.09.2015 (Fig. 3), B-Erzberger 20650, HCsN 7320.

A new occurrence of the species was discovered in the Western Mecsek Mountains and published by CsikY et al. (2014). Associated bryophytes at this site include: Dicranella heteromalla, Poblia nutans (Hedw.) Lindb., Sphagnum capillifolium (Ehrh.) Hedw. var. tenerum (Sull. et Lesq. ex Sull.) Crum (conf./det. W. Schröder), S. fallax (H. Klinggr.) H. Klinggr., and S. squarrosum Crome.

Sterile C. pyriformis is very similar to Dicranella heteromalla, unless the typical spoon-shaped deciduous leaves are present. Otherwise, it can be distinguished by the anatomy of the costa.

\section{Cephaloziella hampeana (Nees) Schiffn.}

Amended red list status: $\mathrm{DD}(\mathrm{IUCN})$.

Gerecse Mts - [8278.3] Komárom-Esztergom county, Western slope of Gete Hill near Tokod, along tourist path (marked blue), on soil near the path between sandstone outcrops, $47.71247^{\circ} \mathrm{N}$, $18.67100^{\circ}$ E, 240 m; leg. P. Erzberger accompanied by Cs. Németh, B. Papp, 20.09.2014, B-Erzberger 18790 (rev. L. Meinunger and W. Schröder 20.02.2015).

Not rare according to Boros (1968), but revision of specimens seems desirable. Probably overlooked as $C$. divaricata (Sm.) Schiffn.

This pale green species, which never shows any tinge of red (becoming brownish in exposed sites), is characterised by an autoicous sexual condition, the complete lack of underleaves on sterile shoots, and moderately large, thin-walled cells, 10-15 $\mu \mathrm{m}$ wide, at the base of lobes, which are 6-10 cells wide. It is most closely related to $C$. varians (Gottsche) Steph., from which it differs in particular by its ecology: $C$. hampeana is calciphobe, whereas $C$. varians requires a basic or calcareous substrate. Although in $C$. varians the underleaves are often inconspicuous, they usually can be detected near the shoot tip. Further differences are: just ripe spores 7-9 $\mu \mathrm{m}$ in C. hampeana, 9-12 $\mu \mathrm{m}$ in C. varians; gemmae colourless, turning partly greyish to rose-brown in $C$. hampeana, whereas in $C$. varians they soon become red; the leaves of $C$. hampeana are flat, squarrosely patent, the leaves of $C$. varians are \pm concave, with the tips turned towards the stem.

\section{Cinclidotus danubicus Schiffn. et Baumgartner}

Amended red list status: DD(IUCN). Candidate for new European red list (HodgetTs 2015).

Szigetköz - [8171.3] Győr-Moson-Sopron county, on submerged rock in the river Danube near Ásványráró, $47.84889^{\circ} \mathrm{N}, 17.50222^{\circ} \mathrm{E}, 110 \mathrm{~m}$; leg. A. Mesterházy, P. Erzberger, Cs. Németh, A. Kovács, A. Rigó, K. Nagy, 10.07.2015, HCsN 7061 (det. P. Erzberger). Associated bryophyte: Cinclidotus riparius (Brid.) Arn. 
This rare species had been found along the Danube between Rajka and Piszke, always in small quantity and in deeper water than the other Cinclidotus species (Boros 1968). Possibly overlooked as C. riparius or C. fontinaloides (Hedw.) P. Beauv.

It differs from its Hungarian congeners, with which it usually grows together, in leaf shape (margins not parallel, leaves widest at base, gradually narrowed to apex), by weaker border and larger laminal cells $(12-15 \mu \mathrm{m}$; rarely to $19 \mu \mathrm{m}$; e.g. $C$. riparius: $8-10 \mu \mathrm{m})$. Similarly to $C$. fontinaloides, the leaves are curled when dry, but only slightly so.

\section{Conardia compacta (Müll. Hal.) H. Rob.}

Amended red list status: NT. Candidate for new European red list (HoDGETTS 2015).

Bakony Mts - [8673.1] Veszprém county, eastern part of Alsó-Cuha-szurdok near Bakonyszentlászló, under overhanging dolomite rocks, $47.37900^{\circ} \mathrm{N}, 17.83550^{\circ} \mathrm{E}, 245 \mathrm{~m}$; leg. Cs. Németh and P. Erzberger, 26.05.2013, B-Erzberger 16246, HCsN 4889. Associated bryophyte: Eucladium verticillatum. - [8675.3] Fejér county, Gaja Gorge near Fehérvárcsurgó, in a small cave named Rigó-lyuk, $47.31097^{\circ} \mathrm{N}, 18.21764^{\circ} \mathrm{E}, 182 \mathrm{~m}$; leg. Cs. Németh, 25.12.2013, HCsN 5162. - [8772.1] Bakonybél, Odvaskő-barlang (Boros 1968, NÉMETH 2011). - [8872.2] Márkó, Slézinger-völgy (NÉmeth 2011). - [8773.4] Eplény, Tobán-Hill (NÉmETH 2011). - [8774.4] Várpalota, Vár-völgy (NÉMETh 2011). - [8775.1] Isztimér, Burok-völgy (Boros 1968, NÉMETh 2011). - [8871.2] Veszprém county, Köves Stream near Farkasgyepü, under overhanging dolomite rocks at Csurgókút, $47.18525^{\circ} \mathrm{N}, 17.59644^{\circ} \mathrm{E}, 320 \mathrm{~m}$; leg. Cs. Németh and P. Erzberger, 01.06.2013, B-Erzberger 16328, HCsN 4920 (Boros 1968). Associated bryophyte: Eucladium verticillatum. - [8872.4] Szentgál, Miklóspál-hegy (NÉmeth 2011). - Balaton Uplands - [8973.4] Veszprém county, Kö Hill (Ember-szikla) near Szentkirályszabadja, in a small dolomite rock cavity, $47.04922^{\circ} \mathrm{N}$, $17.98647^{\circ}$ E, 240 m; leg. Cs. Németh, B. Papp and P. Erzberger, 09.07.2011, HCsN 3671/3 (cf. Boros 1968). - Buda Mts - [8479.1] Pest county, Kutya Hill near Nagykovácsi, on dolomite wall of a small depression, $47.59556^{\circ} \mathrm{N}, 18.83822^{\circ} \mathrm{E}, 425 \mathrm{~m}$; leg. Cs. Németh and G. Mészáros, 21.05.2014, HCsN 5520. - Keszthely Mts - [9169.1] Zala county, Púpos Hill near Rezi, on dolomite rocks at the entrance of a small cave, $46.86875^{\circ} \mathrm{N}, 17.22400^{\circ} \mathrm{E}, 300 \mathrm{~m}$; leg. Cs. Németh and P. Erzberger, 08.10.2013, HCsN 5095. - [9169.4] Zala county, dolomite hills south of the village Vállus, at the entrance of the cave Vadlány-lik, $46.84386^{\circ} \mathrm{N}, 17.30731^{\circ} \mathrm{E}, 290 \mathrm{~m}$; leg. Cs. Németh and P. Erzberger, 07.10.2013, B-Erzberger 16704, HCsN 5067/1. Associated bryophyte: Gymnostomum calcareum. - Vértes Mts - [8676.2] Csákvár, Báracházi-barlang (cave) (NÉMETH 2011). Associated bryophyte: Rhynchostegiella tenella (Dicks.) Limpr. - [8576.2] Gánt (Vérteskozma), Fáni-völgy, Vértesboglár, Macskagödör (NÉMETH 2011). Associated bryophytes: Isopterygiopsis pulchella, Gymnostomum calcareum, Cololejeunea calcarea (Lib.) Schiffn., Orthothecium intricatum. - [8676.1] Gánt, Juh-völgy (NÉMETH 2011).

Four old records published by Boros (1968) were re-confirmed, seven recent records had been published by NÉmETH (2011), five additional records are complemented here. Many of the occurrences are in protected areas, and habitat quality appears to be stable. 
Calcicole species growing in caves, rock cavities, under overhanging rocks, rarely (not seen recently) on saline ground, always in small coverage. It is characterised by filiform gemmae originating from the costa near the leaf apex.

\section{Fissidens gymnandrus Büse}

(Figs 4-5)

Amended red list status: NT. Candidate for new European red list (HoDGETTS 2015).

Danube inundation area - [8178.4] Komárom-Esztergom county, Danube bank at EsztergomBúbánatvölgy, on silt-covered tree trunk in riverine forest, $47.81397^{\circ} \mathrm{N}, 18.81611^{\circ} \mathrm{E}, 113 \mathrm{~m}$; leg. P. Erzberger, 21.09.2015, B-Erzberger 20563. Associated bryophyte: Leskea polycarpa Ehrh. ex Hedw. - [8179.3] Komárom-Esztergom county, Danube bank at Pilismarót-Basaharc near the ferry to Szob, on silt-covered tree trunk in riverine forest, $47.80994^{\circ} \mathrm{N}, 18.87142^{\circ} \mathrm{E}, 105 \mathrm{~m} ;$ leg. P. Erzberger, 23.09.2015, B-Erzberger 20615. - [8179.4] Pest county, Danube bank at Kisoroszi on the island of Szentendre near Szigetcsúcs, on silt-covered tree trunks in riverine forest, $47.80569^{\circ} \mathrm{N}, 18.98514^{\circ} \mathrm{E}$, 100 m; leg. P. Erzberger, 31.07.2015, B-Erzberger 20288. Associated bryophytes: Barbula unguiculata Hedw., Bryoerythrophyllum recurvirostrum (Hedw.) P. C. Chen, Leskea polycarpa. - [8180.3] Pest county, at the south bank of the island of Szentendre at Kisoroszi, near the ferry to Visegrád, on siltcovered tree trunk in riverine forest, $47.80689^{\circ} \mathrm{N}, 19.00186^{\circ} \mathrm{E}, 105 \mathrm{~m}$; leg. P. Erzberger, 28.09.2015, B-Erzberger 20633. - [8271.2] Győr-Moson-Sopron county, Danube bank near Györzámoly, on siltcovered tree trunk in riverine forest, $47.79319^{\circ} \mathrm{N}, 17.64725^{\circ} \mathrm{E}, 110 \mathrm{~m}$; leg. Cs. Németh and P. Erzberger, 04.10.2015, HCsN 7343. - [8272.1] Györ-Moson-Sopron county, Danube bank at Nagybajcs, on silt-covered tree trunk in riverine forest, $47.76672^{\circ} \mathrm{N}, 17.69439^{\circ} \mathrm{E}, 115 \mathrm{~m}$; leg. Cs. Németh and P. Erzberger, 04.10.2015, B-Erzberger 20698, HCsN 7341. - [8274.2] Komárom-Esztergom county, Danube bank near Monostori erőd at Komárom, moist clay at stream bank, $47.75411^{\circ} \mathrm{N}, 18.09092^{\circ} \mathrm{E}, 105$ $\mathrm{m}$; leg. P. Erzberger and Cs. Németh, 02.07.2012, B-Erzberger 15429. Associated bryophytes: Pohlia wablenbergii (F. Weber et D. Mohr) A. L. Andrews, Amblystegium serpens. - [8274.3] Komárom-Esztergom county, Szent Pál-sziget near Komárom-Koppánymonostor, on silt-covered tree trunk in riverine forest, $47.74908^{\circ} \mathrm{N}, 18.02842^{\circ} \mathrm{E}, 120 \mathrm{~m}$; leg. Cs. Németh, 24.09 .2015 (Fig. 4), HCsN 7293, 7294. [8275.3] Komárom-Esztergom county, Szőnyi-sziget at Komárom-Szőny, on silt-covered tree trunk in riverine forest, $47.73806^{\circ} \mathrm{N}, 18.17722^{\circ} \mathrm{E}, 110 \mathrm{~m}$; leg. Cs. Németh, 24.09.2015, HCsN 7308. - [8277.2] Komárom-Esztergom county, Danube bank at Tát near the cemetery, on silt-covered tree trunk in riverine forest, $47.75161^{\circ} \mathrm{N}, 18.62594^{\circ} \mathrm{E}, 105 \mathrm{~m}$; leg. Cs. Németh and P. Erzberger, 22.09.2015, BErzberger 20593. - [8279.2] Pest county, Danube bank east of Dömös, on silt-covered tree trunk in riverine forest, $47.76128^{\circ} \mathrm{N}, 18.93567^{\circ} \mathrm{E}, 100 \mathrm{~m}$; leg. P. Erzberger, 23.09.2015, B-Erzberger 20623. - [8280.1] Pest county, Danube bank on island of Szentendre at Tahitótfalu, on fallen trees and base of tree trunks in riverine forest, $47.76408^{\circ} \mathrm{N}, 19.07753^{\circ} \mathrm{E}, 105 \mathrm{~m}$; leg. P. Erzberger, 23.03.2014, B-Erzberger $17197-17199$; and $47.78383^{\circ} \mathrm{N}, 19.07897^{\circ} \mathrm{E}, 105 \mathrm{~m}$; leg. P. Erzberger, 31.07.2015, B-Erzberger 20299. Associated bryophytes: Leptodictyum riparium, Homalia trichomanoides (Hedw.) Brid., Leskea polycarpa. - [8280.2] Pest county, Danube bank on island of Szentendre at Tahitótfalu near the ferry to Vác, on soil and base of tree trunks in riverine forest, $47.77244^{\circ} \mathrm{N}, 19.12017^{\circ} \mathrm{E}, 105 \mathrm{~m}$; leg. P. Erzberger, 31.07.2015, B-Erzberger 20304, 20305. Associated bryophytes: Fissidens taxifolius Hedw., Leskea polycarpa. - [8280.4] Pest county, Danube bank at Sződliget, on fallen trees and base of tree trunks in riverine forest, $47.74892^{\circ} \mathrm{N}, 19.13669^{\circ} \mathrm{E}, 108 \mathrm{~m}$; leg. P. Erzberger, 09.08.2012, B-Erzberger 15686. Associated bryophytes: Amblystegium varium (Hedw.) Lindb., Brachythecium salebrosum, Bryum pseudotriquetrum (Hedw.) P. Gaertn., E. Mey. et Scherb. - [8380.1] Pest county, western bank of the island 


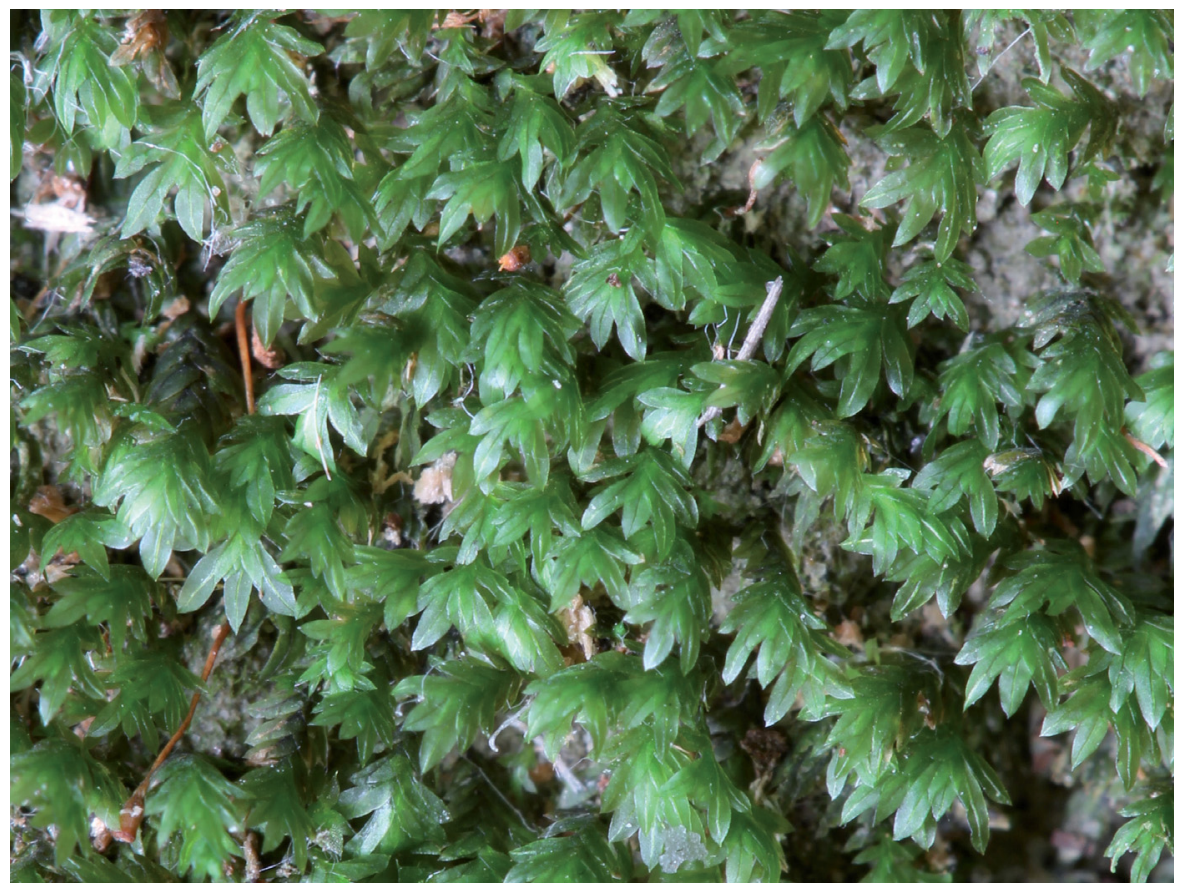

Fig. 4. Fissidens gymnandrus, Danube inundation area, Komárom-Koppánymonostor, Szent Pálsziget (photo: Cs. Németh, 24.09.2015 [8274.3]).

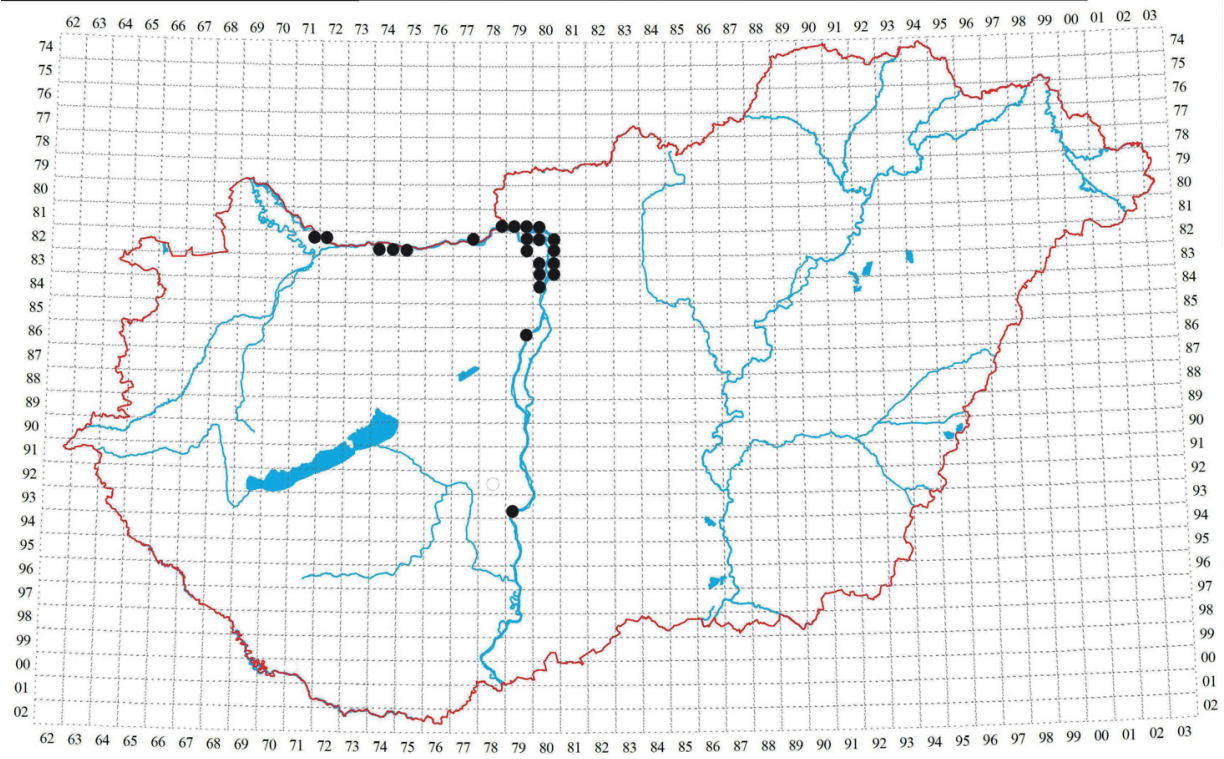

Fig. 5. Records of Fissidens gymnandrus. 
of Szentendre at Szigetmonostor, south of the ferry to Szentendre, on silt-covered base of tree stump in riverine forest, $47.65186^{\circ} \mathrm{N}, 19.08022^{\circ} \mathrm{E}, 120 \mathrm{~m}$; leg. P. Erzberger, 22.10.2015, B-Erzberger 20895. Associated bryophytes: Leskea polycarpa, Bryum moravicum Podp. - [8380.2] Pest county, western bank of the island of Szentendre at Szigetmonostor, south of the ferry to Szentendre, on silt-covered base of tree stump in riverine forest, $47.68161^{\circ} \mathrm{N}, 19.08886^{\circ} \mathrm{E}$, ca $115 \mathrm{~m}$; leg. P. Erzberger, 18.10 .2015 , B-Erzberger 20886. Associated bryophyte: Leskea polycarpa. - [8380.3] Pest county, western bank of the island of Szentendre at Szigetmonostor, south of the ferry to Szentendre, on silt-covered base of tree in riverine forest, $47.64572^{\circ} \mathrm{N}, 19.08117^{\circ} \mathrm{E}, 110 \mathrm{~m}$; leg. P. Erzberger, 22.10.2015, B-Erzberger 20896. Associated bryophyte: Leskea polycarpa. - [8380.4] Pest county, western bank of the island of Szentendre at Szigetmonostor, south of the ferry to Szentendre, on silt-covered base of tree in riverine forest, $47.63700^{\circ} \mathrm{N}, 19.08875^{\circ} \mathrm{E}, 120 \mathrm{~m}$; leg. P. Erzberger, 22.10.2015, B-Erzberger 20911. Associated bryophyte: Leskea polycarpa. - [8480.1] Pest county, western bank of the island of Szentendre south of Szigetmonostor near the south end of the island, on silt-covered base of tree in riverine forest, $47.59950^{\circ} \mathrm{N}, 19.07392^{\circ} \mathrm{E}, 110 \mathrm{~m}$; leg. P. Erzberger, 22.10.2015, B-Erzberger 20914/A. Associated bryophyte: Leskea polycarpa. - [8679.2] Pest county, island of Csepel, west of Halásztelek, on siltcovered base of tree in riverine forest, $47.37697^{\circ} \mathrm{N}, 18.97361^{\circ} \mathrm{E}, 115 \mathrm{~m}$; leg. P. Erzberger, 03.11.2015, B-Erzberger 21033. Associated bryophyte: Leskea polycarpa. - [9379.3] Tolna county, small backwater near the Danube bank at Paks, on silt-covered tree trunk in riverine forest, $46.63581^{\circ} \mathrm{N}, 18.87814^{\circ}$ E, 90 m; leg. P. Erzberger, 14.10.2015, B-Erzberger 20848. - Visegrád Mts - [8279.4] Pest county, Bükkös-patak Valley south of Pilisszentlászló, near Kárpát-forrás, on andesite boulder at the stream; $47.70697^{\circ} \mathrm{N}, 18.97733^{\circ} \mathrm{E}, 310 \mathrm{~m}$; leg. P. Erzberger and Cs. Németh, 04.06.2014, B-Erzberger 17943.

This species apparently occurs regularly in its typical habitat in riverine forests along great rivers mostly on living tree trunks subject to regular inundation. It is characterised by naked antheridia in leaf axils, unlike the bud-like dwarf male branches in F. bryoides, and a broader, mostly obtuse leaf apex. F. gymnandrus had obviously not been well understood by Hungarian bryologists, since no specimens of F. gymnandrus could be identified in the whole material of Fissidens collected in Hungary in BP, and specimens labelled F. gymnandrus (or F. bryoides Hedw. var. gymnandrus) turned out to belong to other taxa, e.g. F. bryoides s. str., F. viridulus (Sw. ex anon.) Wahlenb., F. incurvus Starke ex Röhl., F. gracilifolius (revision of specimens in BP, Erzberger, unpublished).

Fossombronia wondraczekii (Corda) Dumort. ex Lindb.

(Fig. 6)

\section{Amended red list status: EN.}

Bakony Mts - [8971.2] Veszprém county, Kab Hill near Nagyvázsony, north of pond Nyír-tó, on moist mud at the bank of a small pond, $47.05439^{\circ} \mathrm{N}, 17.61100^{\circ} \mathrm{E}, 420 \mathrm{~m}$; leg. P. Erzberger and B. Papp, 13.07.2012, B-Erzberger 15535, 15536. Associated bryophytes: Poblia lescuriana (Sull.) Ochi, Pseudephemerum nitidum (Hedw.) Loeske. - Örség - [9065.4] Vas county, Csonka-erdő near Nádasd, on the edge of an artificial woodland pond, $46.93750^{\circ} \mathrm{N}, 16.58472^{\circ} \mathrm{E}, 260 \mathrm{~m}$; leg. A. Mesterházy, 10.07.2015, HCsN 7170 (det. Cs. Németh, conf. P. Erzberger). Associated bryophytes: Pleuridium acuminatum Lindb. - [9163.2] Vas county, on moist forest tracks near the pond Fekete-tó at Orfalu, $46.88531^{\circ} \mathrm{N}, 16.28944^{\circ} \mathrm{E}, 280 \mathrm{~m}$; leg. P. Erzberger and Cs. Németh, 29.07.2014, B-Erzberger 18561, 18563, HCsN 5984; associated bryophytes: Bryum pallens, Hypnum lindbergii Mitt., Pleuridium subu- 


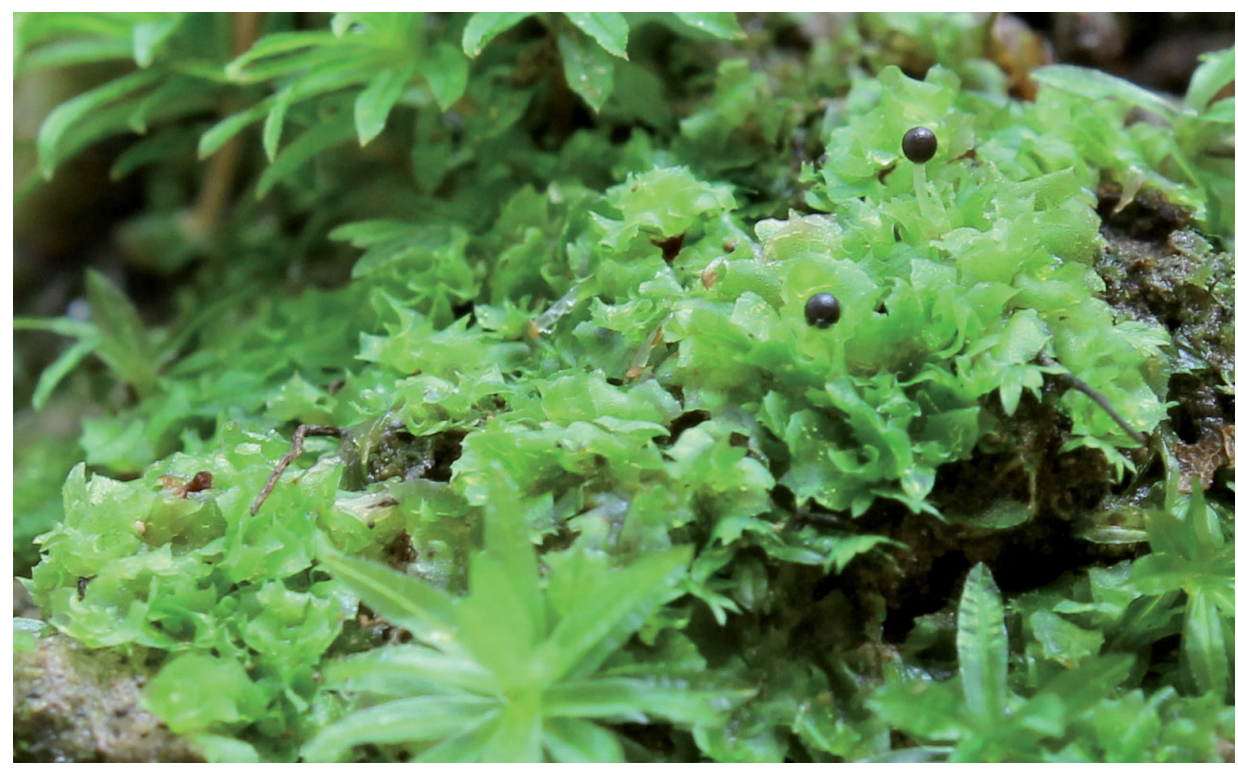

Fig. 6. Fossombronia wondraczekii, Vendvidék, Szakonyfalu, Grajka Stream Valley (photo: Cs. Németh, 31.07.2014 [9063.3]).

latum, Scapania irrigua (Nees) Nees, and $46.88333^{\circ} \mathrm{N}, 16.29533^{\circ} \mathrm{E}, 310 \mathrm{~m}$; leg. P. Erzberger and Cs. Németh, 29.07.2014, B-Erzberger 18591; associated bryophytes: Atrichum angustatum (Brid.) Bruch et Schimp., Pohlia lescuriana, Ephemerum minutissimum Lindb., Pleuridium subulatum, Ditrichum pallidum (Hedw.) Hampe, Fissidens bryoides, Cephalozia bicuspidata (L.) Dumort., Scapania irrigua. - Vendvidék - [9063.3] Vas county, Grajka Stream Valley south of the village Szakonyfalu, on moist abandoned forest track $46.90572^{\circ} \mathrm{N}, 16.23386^{\circ} \mathrm{E}, 265 \mathrm{~m}$; leg. P. Erzberger and Cs. Németh, 31.07.2014 (Fig. 6), B-Erzberger 18635, HCsN 6039. Associated bryophytes: Pseudephemerum nitidum, Poblia lescuriana, P. melanodon, P. wablenbergii, Physcomitrium pyriforme, Bryum rubens, Ephemerum minutissimum, Fissidens exilis Hedw., F. viridulus. - Zemplén Mts - [7594.4] BorsodAbaúj-Zemplén county, Komlóska Stream Valley near Nagyhuta, on open soil in wet meadow, $48.42275^{\circ} \mathrm{N}, 21.47183^{\circ}$ E, 265 m; leg. P. Erzberger and B. Papp, 15.04.2006, B-Erzberger 11423, 11424. Associated bryophytes: Ephemerum minutissimum, Pohlia annotina (Hedw.) Lindb.

The species occurs in seven mountain regions according to Boros (1968).

Since spore size and ornamentation are diagnostic, this species can be named with certainty only when sporophytes are present (as in the above-mentioned collections).

\section{Jungermannia atrovirens Dumort.}

Amended red list status: CR.

Börzsöny Mts - [8079.2] Pest county, Kemence Stream ca 3 km below Kemence-Királyháza, andesitic rock at stream bank, $47.99042^{\circ} \mathrm{N}, 18.93703^{\circ} \mathrm{E}, 320 \mathrm{~m}$; leg. P. Erzberger and Cs. Németh, 26.06.2014, B-Erzberger 18224, HCsN 5680 (det. L. Meinunger). 
Boros (1968) reported this very rare species (sub Solenostoma triste (Nees) Müll. Frib.) from three locations: Visegrád Mts (according to Förster), Buda Mts (according to Szepesfalvi), and Bakony Mts.

Unlike most of its Hungarian congeners, this plant grows on limestone and basic rock; it is dioicous, and has hyaline rhizoids (J. hyalina Lyell. has violet rhizoids).

\section{Leiocolea badensis (Gottsche) Jörg.}

(Fig. 7)

Amended red list status: EN.

Bakony Mts - [8871.2] Veszprém county, Köves Stream near Farkasgyepű, on shaded dolomite rock, $47.19019^{\circ} \mathrm{N}, 17.61183^{\circ} \mathrm{E}, 335 \mathrm{~m}$; leg. Cs. Németh and P. Erzberger, 01.06.2013, B-Erzberger 16295, HCsN 4906. - Bükk Mts - [7989.4] Borsod-Abaúj-Zemplén county, Fátyol Waterfall (Szinva-vízesés) at Miskolc-Lillafüred, on wet limestone in the spray-zone of the waterfall, $48.10469^{\circ} \mathrm{N}, 20.62436^{\circ} \mathrm{E}, 300 \mathrm{~m}$; leg. Cs. Németh, A. Mesterházy, A. Schmotzer, V. G. Papp, 08.10.2014 (Fig. 7), HCsN 6330 (det. Cs. Németh, conf. P. Erzberger). Associated bryophytes: Hygrohypnum luridum (Hedw.) Jenn., Didymodon spadiceus (Mitt.) Limpr. (Boros 1968). - Pilis Mts - [8379.3] Pest county, Zajnát Hills near Pilisvörösvár, Vörös Hill, south of summit, on shaded dolomite rock in small cave, $47.62744^{\circ} \mathrm{N}, 18.86708^{\circ} \mathrm{E}, 342 \mathrm{~m}$; leg. Cs. Németh and P. Erzberger,

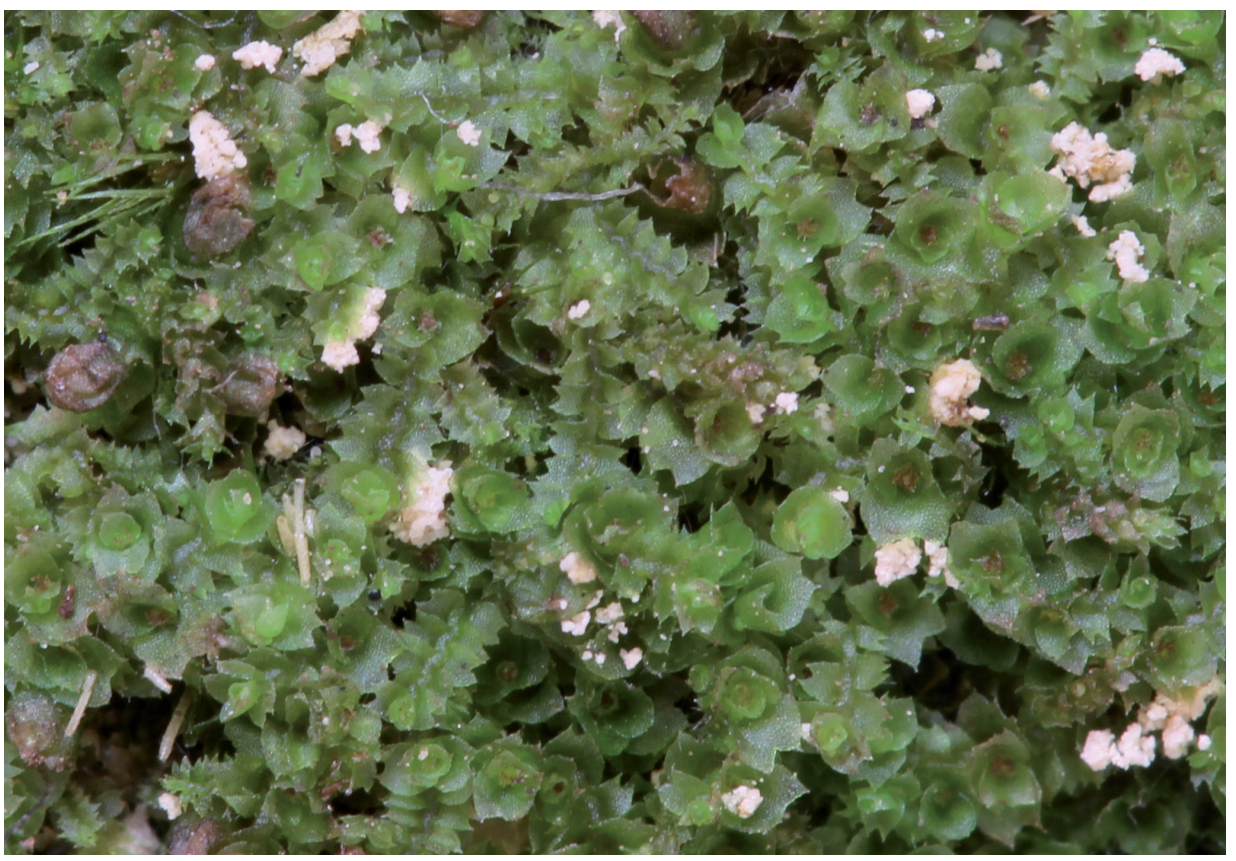

Fig. 7. Leiocolea badensis, Bükk Mts, Miskolc-Lillafüred, Fátyol Waterfall (Szinva-vízesés) (photo: Cs. Németh, 08.10.2014 [7989.4]). 
23.05.2014, B-Erzberger 17732, HCsN 5543. Associated bryophytes: Gymnostomum viridulum Brid., Pseudocrossidium revolutum (Brid.) R. H. Zander.

Reported from four more sites (Buda Mts, Gerecse Mts, Bakony Mts, Zala) in Boros (1968) apart from the re-confirmed site at Lillafüred.

This species is smaller than its Hungarian congeners and lacks underleaves (and the characteristic scent of $L$. collaris (Nees) Schljakov), but shares with them the blunt leaf lobes.

\section{Lophozia sudetica (Huebener) Grolle}

Amended red list status: EN.

Aggtelek Kavicshát - [7588.4] Borsod-Abaúj-Zemplén county, Aggtelek National Park, Aggtelek (Kavicshát), towards Mt Kavicsos Hill near Hármas-határ, $48.44831^{\circ} \mathrm{N}, 20.46986^{\circ} \mathrm{E}, 375 \mathrm{~m}$; leg. B. Papp, 31.05.2010, BP 50526/H. - Börzsöny Mts - [8079.2] Pest county, Kopolya-kövek above Kemence-Királyháza, on andesite rocks, leg. P. Erzberger, 03.04.1994, B-Erzberger 1057 as L. cf. excisa (Dicks.) Dumort. (rev. L. Meinunger 02.2015); associated bryophytes: Diphyscium foliosum (Hedw.) D. Mohr, Pseudotaxiphyllum elegans (Brid.) Z. Iwats.; and B-Erzberger 1063 (det. J. Váňa); associated bryophytes: Cynodontium polycarpon (Hedw.) Schimp. var. strumiferum (Hedw.) Schimp., Tritomaria exsecta (Schmidel) Loeske, Diplophyllum obtusifolium (Hook.) Dumort., Diphyscium foliosum. - Visegrád Mts - [8280.3] Pest county, Vértes Hill above Tahi, andesite rock, leg. P. Erzberger, 07.04.1994, BErzberger 1119 (det. J. Váňa). Associated bryophytes: Cephaloziella divaricata, Pohlia cruda (Hedw.) Lindb., Plagiochila porelloides (Nees) Lindenb., Barbilophozia barbata (Schreb.) Loeske.

Reported by Boros (1968) from five volcanic mountain regions of Northern Hungary (e.g. Börzsöny and Visegrád Mts), but not from the Aggtelek region.

This species can be recognised by clusters of red-brown ripe gemmae in combination with shallowly notched, concave leaves.

\section{Pellia epiphylla (L.) Corda}

(Fig. 8)

Amended red list status: NT.

Örség - [9064.3] Vas county, on loamy stream bank between Csörötnek and Farkasfa, 46.92022 $2^{\circ}$, 16.36028 E, 250 m; obs. P. Erzberger and A. Rigó, 11.08.2015. - [9164.1] Vas county, stream bank SW of Szalafö, $46.85842^{\circ} \mathrm{N}, 16.36142^{\circ} \mathrm{E}, 255 \mathrm{~m}$; leg. P. Erzberger, A. Rigó and K. Baráth, 12.08.2015, B-Erzberger 20424. - [9164.3] Vas county, stream bank SW of Szalafö, $46.84994^{\circ}$ $\mathrm{N}, 16.34681^{\circ} \mathrm{E}, 270 \mathrm{~m}$; leg. P. Erzberger, A. Rigó and K. Baráth, 12.08.2015, B-Erzberger 20431. Associated bryophytes: Fissidens bryoides, Lophocolea bidentata (L.) Dumort. - Vendvidék - [9063.3] Vas county, Grajka Stream Valley near Szakonyfalu, loamy stream bank, $46.90992^{\circ}$ N, $16.22919^{\circ}$ E, 265 m; leg. P. Erzberger and Cs. Németh, 31.07.2014 (Fig. 8), HCsN 6036. Associated bryophytes: Blasia pusilla L., Dicranella schreberiana (Hedw.) Hilf. ex H. A. Crum et L. E. Anderson, Poblia melanodon. - [9063.4] Vas county, bank of Zsida Stream Valley near Szentgotthárd-Zsidahegy, $46.92650^{\circ}$ $\mathrm{N}, 16.27642^{\circ} \mathrm{E}, 270 \mathrm{~m}$; leg. P. Erzberger and Cs. Németh, 30.07.2014, HCsN 6013. Associated bryophyte: Scapania undulata (L.) Dumort. - [9162.2] Vas county, Halál-völgye Valley near Felsőszölnök, stream bank, $46.87128^{\circ} \mathrm{N}, 16.12511^{\circ} \mathrm{E}, 330 \mathrm{~m}$; leg. P. Erzberger, 16.07.2014, B-Erzberger 18466. As- 
sociated bryophyte: Poblia lutescens (Limpr.) H. Lindb. - [9163.1] Vas county, stream valley north of Hegyes Hill near Felsőszölnök, stream bank, $46.86350^{\circ} \mathrm{N}, 16.17222^{\circ} \mathrm{E}, 330 \mathrm{~m}$; leg. P. Erzberger, 17.07.2014, B-Erzberger 18483; associated bryophyte: Pseudephemerum nitidum; and eastern branch of Grajka Stream Valley near Kétvölgy, stream bank, $46.88956^{\circ} \mathrm{N} 16.23342^{\circ} \mathrm{E}, 300 \mathrm{~m}$; leg. P. Erzberger, 18.07.2014, B-Erzberger 18519; associated bryophytes: Pseudephemerum nitidum, Amblystegium humile (P. Beauv.) Crundw., Calypogeia fissa (L.) Raddi, Mnium hornum Hedw.

Boros (1968) considered all reports as doubtful except those from VasiHegyhát. In Örség and Vendvidék, P. epiphylla is not rare. It may have been overlooked for the similar P. endiviifolia (Dicks.) Dumort. The two species can be identified even in the field when fertile, since $P$. endiviifolia is dioicous, with a tubular involucre around the developing sporophyte, whereas $P$. epiphylla is monoicous and has a flap-like involucre. In autumn, $P$. endiviifolia usually produces many narrow, bifurcate branches resembling antlers of a stag, but care is needed, since $P$. epiphylla can also have smaller branches as innovations. One can always tell the two species apart by microscopical examination of the slime papillae at the end of the thallus, preferably in fresh or not too old material: In $P$. endiviifolia these are longer and more-celled, restricted to the underside of the thallus, whereas in $P$. epiphylla they have a one-celled stalk and occur on both sides at the thallus end.

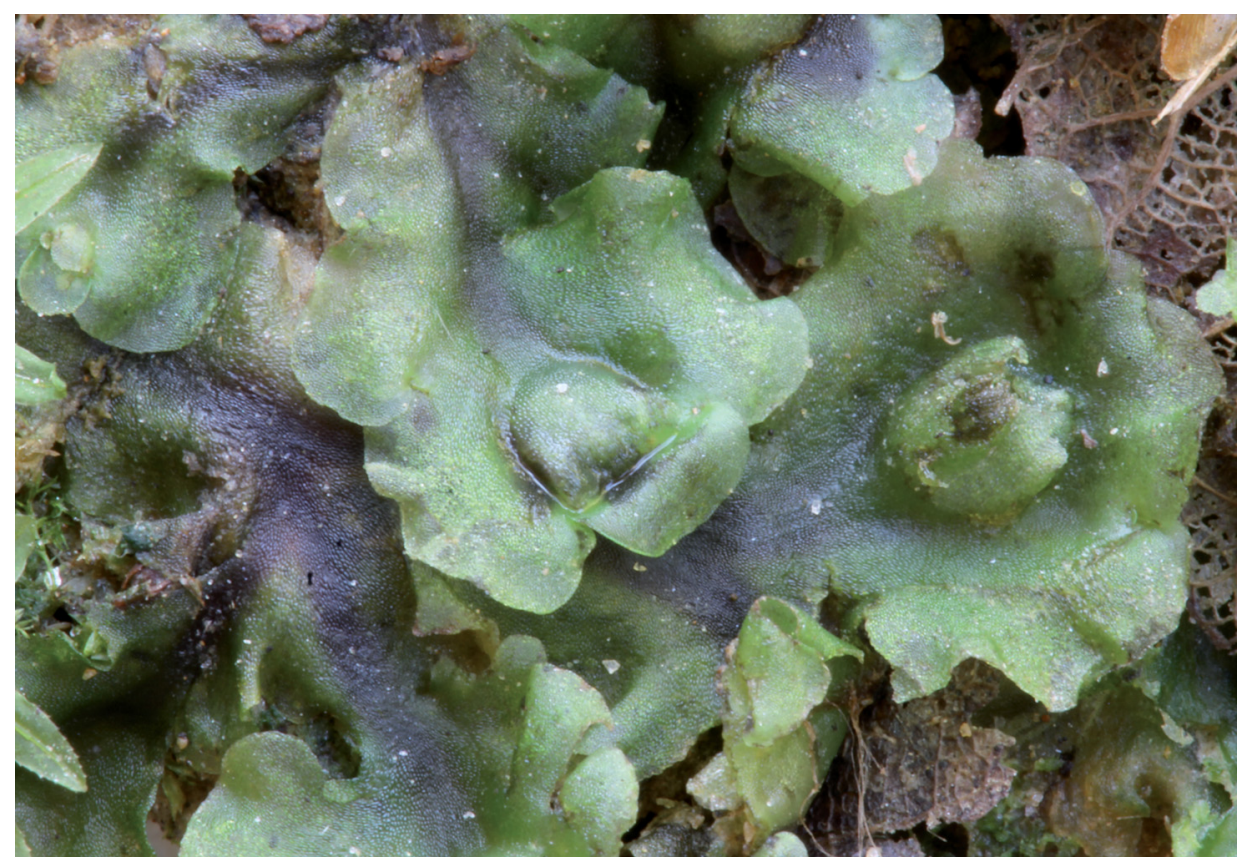

Fig. 8. Pellia epiphylla, Vendvidék, Szakonyfalu, Grajka Stream Valley (photo: Cs. Németh, 31.07.2014 [9063.3]). 


\section{Philonotis calcarea (Bruch et Schimp.) Schimp.}

(Fig. 9)

Amended red list status: EN.

Bükk Mts - [7989.1] Borsod-Abaúj-Zemplén county, Csipkés-kút near Miskolc, spring meadow, on soil, $48.09511^{\circ} \mathrm{N}, 20.50203^{\circ} \mathrm{E}, 785 \mathrm{~m}$; leg. Cs. Németh, A. Mesterházy, A. Schmotzer, V. G. Papp, 08.10.2014 (Fig. 9), HCsN 6338 (det. Cs. Németh, conf. P. Erzberger). Associated bryophytes: Plagiomnium elatum (Bruch et Schimp.) T. J. Kop., Climacium dendroides (Hedw.) F. Weber et D. Mohr, Bryum pseudotriquetrum, Cratoneuron filicinum (Hedw.) Spruce. - Örség [9165.1] Vas county, lower meadows in the valley near Szöce, springs, wetland, leg. P. Erzberger, 16.07.1997, B-Erzberger 3531. Associated bryophytes: Calliergonella cuspidata (Hedw.) Loeske, Bryum pseudotriquetrum, Aulacomnium palustre (Hedw.) Schwägr., Plagiomnium ellipticum (Brid.) R. J. Kop.

This species was reported from eleven regions by Boros (1968); its habitat (calcareous fens and springs) has obviously deteriorated in many cases and become very rare.

Unlike all other Hungarian congeners, $\mathrm{Ph}$. calcarea is strongly calciphilic; from $\mathrm{Ph}$. fontana (Hedw.) Brid. it can be distinguished by the strong costa (60$180 \mu \mathrm{m}$ wide at leaf insertion) and the larger laminal cells in the lower third of the leaf (paracostal cells 12-22 $\mu \mathrm{m}$ wide and 50-80 $\mu \mathrm{m}$ long, \pm hyaline).

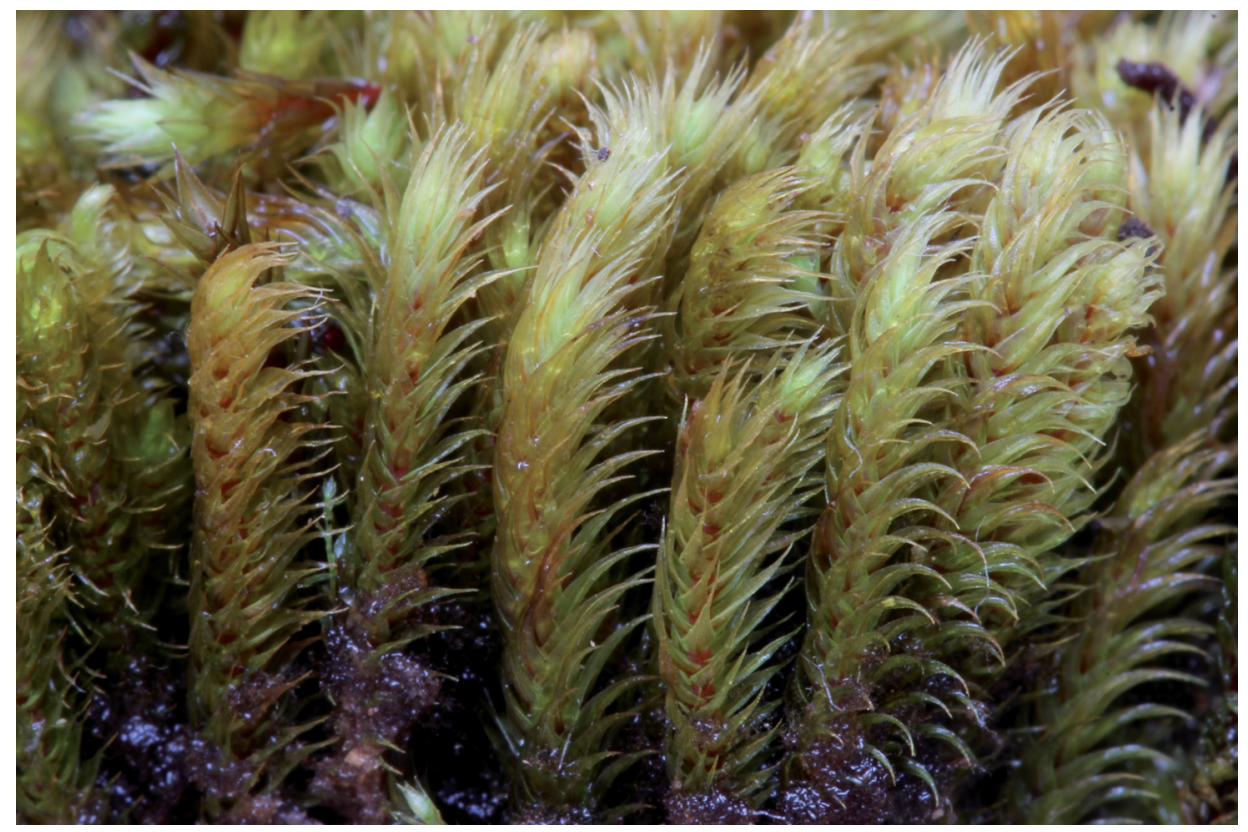

Fig. 9. Philonotis calcarea, Bükk Mts, Miskolc, Csipkés-kút (photo: Cs. Németh, 08.10.2014 [7989.1]). 


\section{Philonotis marchica (Hedw.) Brid.}

Amended red list status: EN. Candidate for new European red list (HoDGETTS 2015).

Bakony Mts - [8873.4] Veszprém county, Mikládi wetland at Gyulafirátót, $47.13250^{\circ} \mathrm{N}$, 17.92044ํㅡ, 200 m; leg. B. Papp, 14.07.2012, BP 187106 (det. B. Papp, conf. P. Erzberger). - Zselic - [9874.3] Baranya county, stream bank near Bükkösd-Gorica, on sinter, $46.14636^{\circ} \mathrm{N}, 18.00278^{\circ} \mathrm{E}$, 250 m; leg. J. Csiky and A. Tóth, 28.07.2010, BP 186246 (det. B. Papp, conf. P. Erzberger). The same locality, towards the water works; leg. J. Csiky and J. Deme, 10.07.2014, JPU s.n. (det. J. Csiky, conf. P. Erzberger). Associated bryophytes: Amblystegium serpens, Cratoneuron filicinum, Eurhynchium hians (Hedw.) Sande Lac., Pellia endiviifolia, Plagiomnium undulatum (Hedw.) T. J. Kop., Pohlia melanodon, P. wablenbergii, Platyhypnidium riparioides.

Philonotis marchica was reported from eleven localities in Boros (1968), from many of which the species has probably been lost due to changes in habitat quality (e.g. abandoned water mills).

A slender species characterised by distal mamillae on nearly all laminal cells and leaf margin not recurved.

\section{Poblia annotina (Hedw.) Lindb.}

Amended red list status: EN.

Mecsek Mts - [9975.1] Baranya county, Éger Valley at Pécs-Ürög, on soil in acidophilous oak forest, $46.09203^{\circ} \mathrm{N}, 18.17389^{\circ} \mathrm{E}, 350 \mathrm{~m}$; leg. P. Erzberger, J. Csiky and D. Kovács, 07.10.2014, B-Erzberger 19055. Associated bryophytes: Gymnocolea inflata (Huds.) Dumort., Scapania praetervisa Meyl., Pogonatum nanum (Hedw.) P. Beauv. - Örség - [9064.3] Vas county, at the bank of artificial lake "Kígyúpásztor-tó" S of Csörötnek, on loamy soil, $46.91844^{\circ} \mathrm{N}, 16.36108^{\circ} \mathrm{E}, 240$ m; leg. P. Erzberger and A. Rigó, 11.08.2015, B-Erzberger 20404. Associated bryophytes: Bryum barnesii J. B. Wood, Fossombronia sp. There is an old occurrence from Öriszentpéter (leg. L. Vajda 1972, Erzberger 2005). - Zemplén Mts - [7594.4] Borsod-Abaúj-Zemplén county, Komlóska Stream Valley near Nagyhuta, on open soil in wet meadow, $48.42275^{\circ} \mathrm{N}, 21.47183^{\circ} \mathrm{E}, 300 \mathrm{~m}$; leg. P. Erzberger and B. Papp, 15.04.2006, B-Erzberger 11424. Associated bryophytes: Fossombronia wondraczekii, Ephemerum minutissimum.

There are several old records from the Zemplén Mts according to the specimens in BP and EGR (revised in ERZBERGER 2005) collected by Boros and Vajda between 1955 and 1967, but not from the above mentioned site. The species was hitherto known from Zemplén Mts, Bakony Mts, Őrség, Vendvidék, and Kőszeg Mts; new to Mecsek Mts (Erzberger 2005).

\section{Pohlia proligera (Kindb.) Lindb. ex Broth.}

Amended red list status: CR.

Visegrád Mts - [8279.4] Pest county, steep roadside under north face of Keserüs Hill near Pilisszentlászló, $47.73833^{\circ} \mathrm{N}, 18.93067^{\circ} \mathrm{E}, 600$ m; leg. P. Erzberger and B. Papp, 30.05.2014, B-Erzberger 17882. Associated bryophytes: Scapania praetervisa, Nardia scalaris Gray, Pogonatum nanum. 
The species was hitherto known from Zemplén Mts, Bakony Mts, Örség, Vendvidék, and Kőszeg Mts; new to Visegrád Mts (ERZBERGER 2005).

\section{Racomitrium affine (F. Weber et D. Mohr) Lindb.}

(Fig. 10)

\section{Amended red list status: EN.}

Börzsöny Mts - [8079.2] Pest county, Kopolya-kövek above Kemence-Királyháza, shady andesite rock, $47.96208^{\circ} \mathrm{N}, 18.94781^{\circ} \mathrm{E}, 730 \mathrm{~m}$; leg. P. Erzberger and B. Papp, 04.08.1999, B-Erzberger 5567, 5572, 5575, BP 170524 (sub R. heterostichum, rev. H. Bednarek-Ochyra) (det. H. Bednarek-Ochyra); associated bryophytes: Racomitrium aquaticum (Schrad.) Brid., Cynodontium polycarpon, Tritomaria exsecta, Cephalozia bicuspidata, Grimmia hartmanii Schimp.; and leg. P. Erzberger, B. Papp and Cs. Németh, 20.06.2014, HCsN 5668 (det. P. Erzberger, conf. H. BednarekOchyra); and Sasfészek-bérc, $47.96486^{\circ} \mathrm{N}, 18.95044^{\circ} \mathrm{E}, 670 \mathrm{~m}$; leg. P. Erzberger, B. Papp and Cs. Németh, 20.06.2014 (Fig. 10), B-Erzberger 18157, 18158, 18167, 18181, 18186, HCsN 5637 (det. P. Erzberger, conf. H. Bednarek-Ochyra); associated bryophytes: Pogonatum nanum, Cynodontium polycarpon, Grimmia muehlenbeckii Schimp.; and boulder scree and rocks $S$ of Sasfészek-bérc above Rózsás Stream Valley, $47.95878^{\circ} \mathrm{N}, 18.95189^{\circ} \mathrm{E}, 760 \mathrm{~m}$; leg. Cs. Németh and P. Erzberger, 26.06.2014, B-Erzberger 18256, HCsN 5701 (det. P. Erzberger, conf. H. Bednarek-Ochyra); associated bryophytes: Lophozia ventricosa (Dicks.) Dumort., Leucobryum glaucum (Hedw.) Ångstr., Racomitrium canescens (Hedw.) Brid., Rhabdoweisia fugax (Hedw.) Bruch et Schimp., Dicranella heteromalla, Paraleucobryum longifolium (Hedw.) Loeske, Diphyscium foliosum. - Balaton Uplands

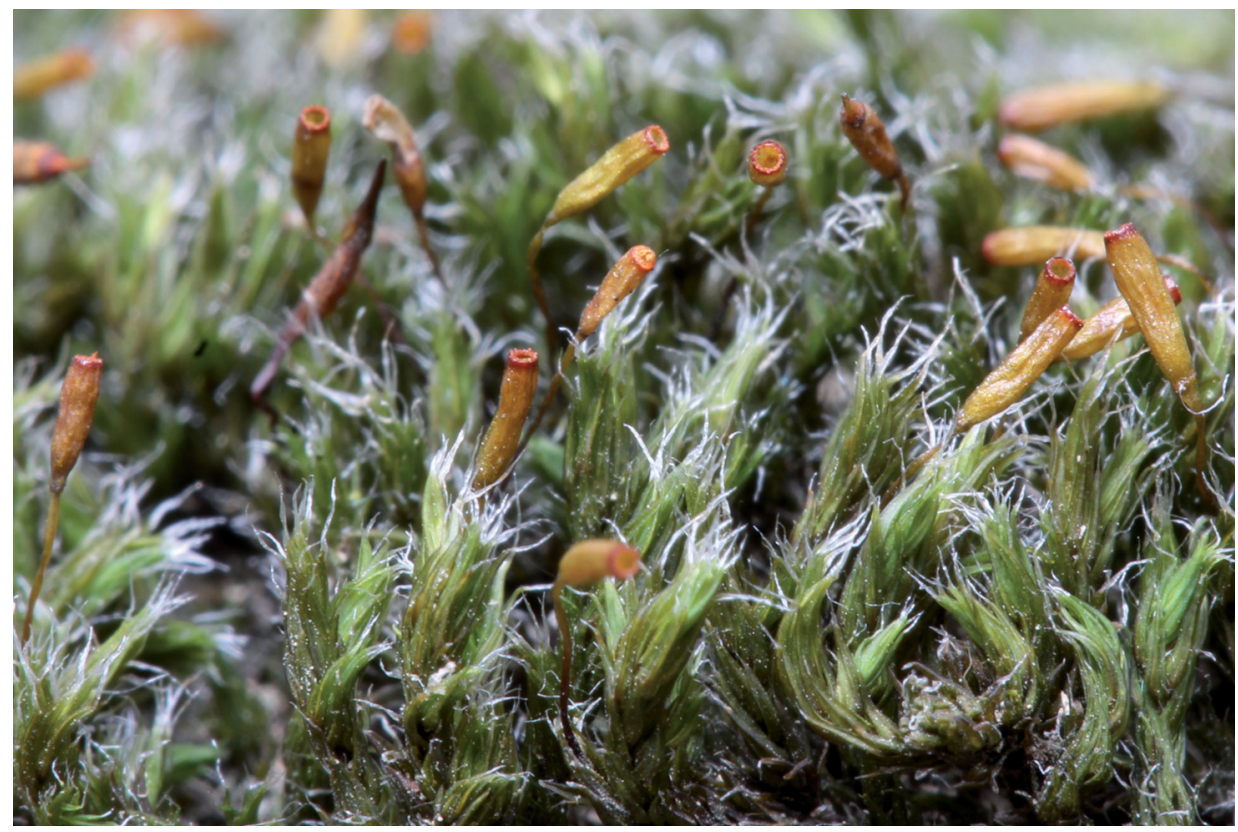

Fig. 10. Racomitrium affine, Börzsöny Mts, Kemence-Királyháza, Sasfészek-bérc (photo: Cs. Németh, 20.06.2014 [8079.2]). 
- [9171.1] Veszprém county, Köves Hill near Mindszentkálla, basalt boulder scree $46.87617^{\circ} \mathrm{N}$, $17.52594^{\circ}$ E, 210 m; leg. P. Erzberger and Cs. Németh, 28.09.2014, B-Erzberger 18909 (det. P. Erzberger, conf. H. Bednarek-Ochyra). Associated bryophytes: Grimmia decipiens (Schultz) Lindb., G. pulvinata (Hedw.) Sm., G. laevigata (Brid.) Brid., G. longirostris Hook., G. muehlenbeckii, Schistidium apocarpum (Hedw.) Bruch et Schimp.

Reported by Boros (1968) from the Börzsöny Mts (Sasfészek, Bacsina Valley); new to Balaton Uplands.

\section{Riccia bifurca Hoffm. \\ (Figs 11-12)}

\section{Amended red list status: NT.}

Bakony Mts - [8672.2] Veszprém county, moist forest track in spruce plantation west of Bakonyszentlászló-Vinye, $47.35939^{\circ} \mathrm{N}, 17.80569^{\circ} \mathrm{E}, 275 \mathrm{~m}$; leg. P. Erzberger and Cs. Németh, 31.07.2013 (Fig. 11), B-Erzberger 16570 as R. glauca var. subinermis (Lindb.) Warnst. (rev. L. Meinunger). Associated bryophytes: Atrichum undulatum (Hedw.) P. Beauv., Cephaloziella divaricata. - Danube inundation area - [8179.3] Komárom-Esztergom county, Danube bank at PilismarótBasaharc, near the ferry to Szob, on drying mud, $47.80994^{\circ} \mathrm{N}, 18.87142^{\circ} \mathrm{E}, 105 \mathrm{~m}$; leg. P. Erzberger, 23.09.2015, B-Erzberger 20606. Associated bryophytes: Aphanorrhegma patens (Hedw.) Lindb., Riccia frostii. - [8179.4] Pest county, Danube bank on island of Szentendre at Kisoroszi near Szigetcsúcs, on drying mud, $47.80672^{\circ} \mathrm{N}, 18.98942^{\circ} \mathrm{E}, 100 \mathrm{~m}$; leg. P. Erzberger, 28.09.2015, B-Erzberger 20629. Associated bryophytes: Aphanorrhegma patens, Riccia glauca, $R$. frostii, Ricciocarpos natans (L.) Corda. - [8180.3] Pest county, south bank of the island of Szentendre at Kisoroszi, near the ferry to Visegrád, $47.80689^{\circ} \mathrm{N}, 19.00186^{\circ} \mathrm{E}, 100 \mathrm{~m}$; leg. P. Erzberger, 28.09.2015, B-Erzberger 20632. Associated bryophyte: Aphanorrhegma patens. - [8180.4] Pest county, on the island of Szentendre between Tahitótfalu and Kisoroszi, Danube bank opposite the cement factory of Vác, on drying mud, $47.80014^{\circ} \mathrm{N}, 19.08539^{\circ} \mathrm{E}, 100 \mathrm{~m}$; leg. P. Erzberger, 02.10.2015, B-Erzberger 20682/B. Associated bryophytes: Aphanorrhegma patens, Riccia cavernosa, R. frostii, R. glauca. - [8272.1] Győr-Moson-Sopron county, Szigetköz, Danube bank at Nagybajcs, on drying mud, $47.76811^{\circ}$ N, $17.69322^{\circ}$ E, 115 m; leg. Cs. Németh and P. Erzberger, 04.10.2015, B-Erzberger 20688. Associated bryophyte: Aphanorrhegma patens. - [8277.2] Komárom-Esztergom county, Danube bank at Tát near the cemetery, on drying mud, $47.75319^{\circ} \mathrm{N}, 18.62597^{\circ} \mathrm{E}, 105 \mathrm{~m}$; leg. Cs. Németh and P. Erzberger, 22.09.2015, B-Erzberger 20590. Associated bryophytes: Riccia frostii Austin, R. rhenana Lorb. ex Müll. Frib. - [8279.1] Komárom-Esztergom county, Danube bank north of Dömös, on drying mud, $47.77536^{\circ} \mathrm{N}, 18.90581^{\circ} \mathrm{E}, 100 \mathrm{~m}$; leg. P. Erzberger, 28.10.2015, B-Erzberger 20964. Associated bryophytes: Riccia frostii, Aphanorrhegma patens. - [8279.2] Pest county, Danube bank east of Dömös, on drying mud, $47.76128^{\circ} \mathrm{N}, 18.93567^{\circ} \mathrm{E}, 100 \mathrm{~m}$; leg. P. Erzberger, 23.09.2015, B-Erzberger 20618/A. Associated bryophytes: Aphanorrhegma patens, Riccia cavernosa, R. frostii. [8280.1] Pest county, island of Szentendre at Tahitótfalu, Danube bank near Kecske-zátony, on drying mud, $47.76372^{\circ} \mathrm{N}, 19.07594^{\circ} \mathrm{E}, 100 \mathrm{~m}$; leg. P. Erzberger, 23.09.2015, B-Erzberger 20624. Associated bryophytes: Aphanorrhegma patens, Riccia cavernosa, $R$. frostii. - [8380.1] Pest county, island of Szentendre at Szigetmonostor, on drying mud at the western bank of the island, south of the ferry to Szentendre old town, $47.65367^{\circ} \mathrm{N}, 19.08086^{\circ} \mathrm{E}, 95 \mathrm{~m}$, leg. P. Erzberger, 22.10.2015, B-Erzberger 20892, 20893. Associated bryophytes: Aphanorrhegma patens, Riccia cavernosa, R. glauca, $R$. frostii. - [8380.2] Pest county, island of Szentendre at Szigetmonostor, western bank of the island, north of the ferry to Szentendre-Határcsárda, on drying mud at the riverbank, $47.69950^{\circ} \mathrm{N}, 19.09258^{\circ} \mathrm{E}$, 100 m; leg. P. Erzberger, 18.10.2015, B-Erzberger 20873/A. Associated bryophytes: Aphanorrheg- 


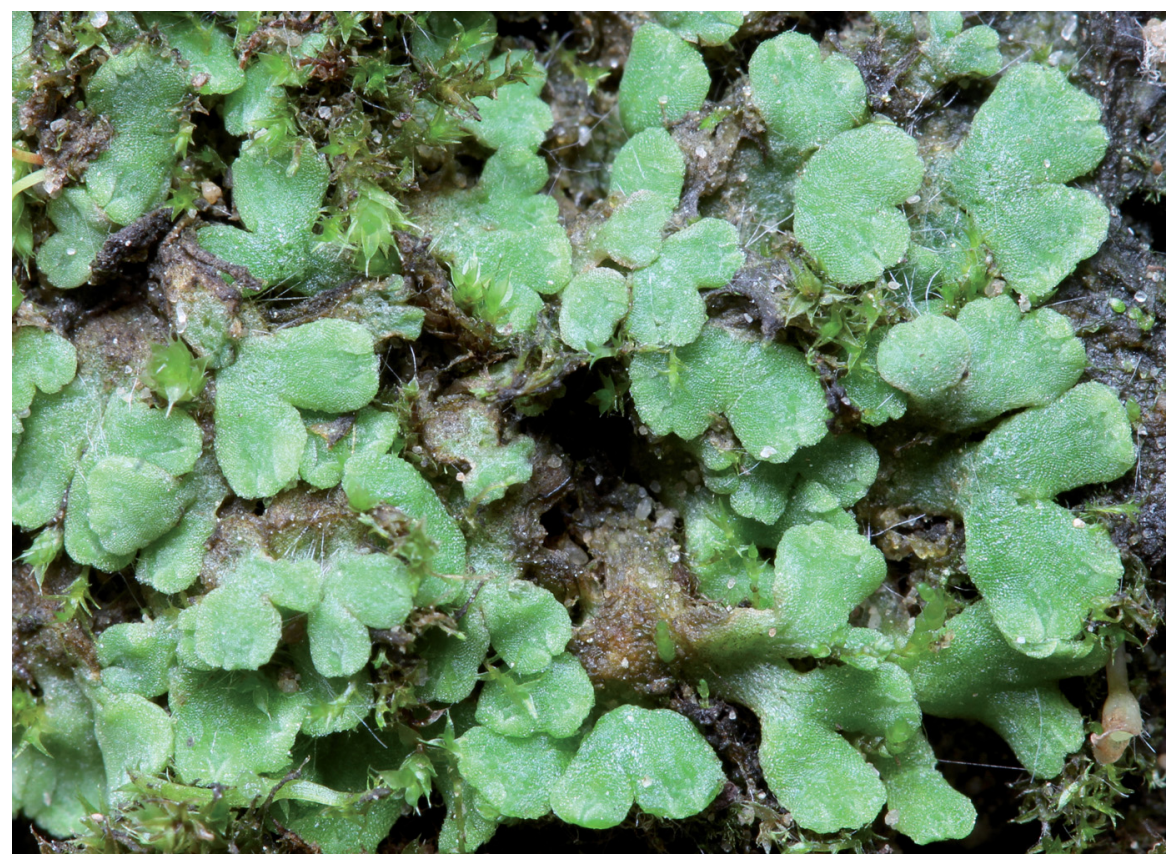

Fig. 11. Riccia bifurca, Bakony Mts, Bakonyszentlászló-Vinye (photo: Cs. Németh, 31.07.2013 [8672.2]).

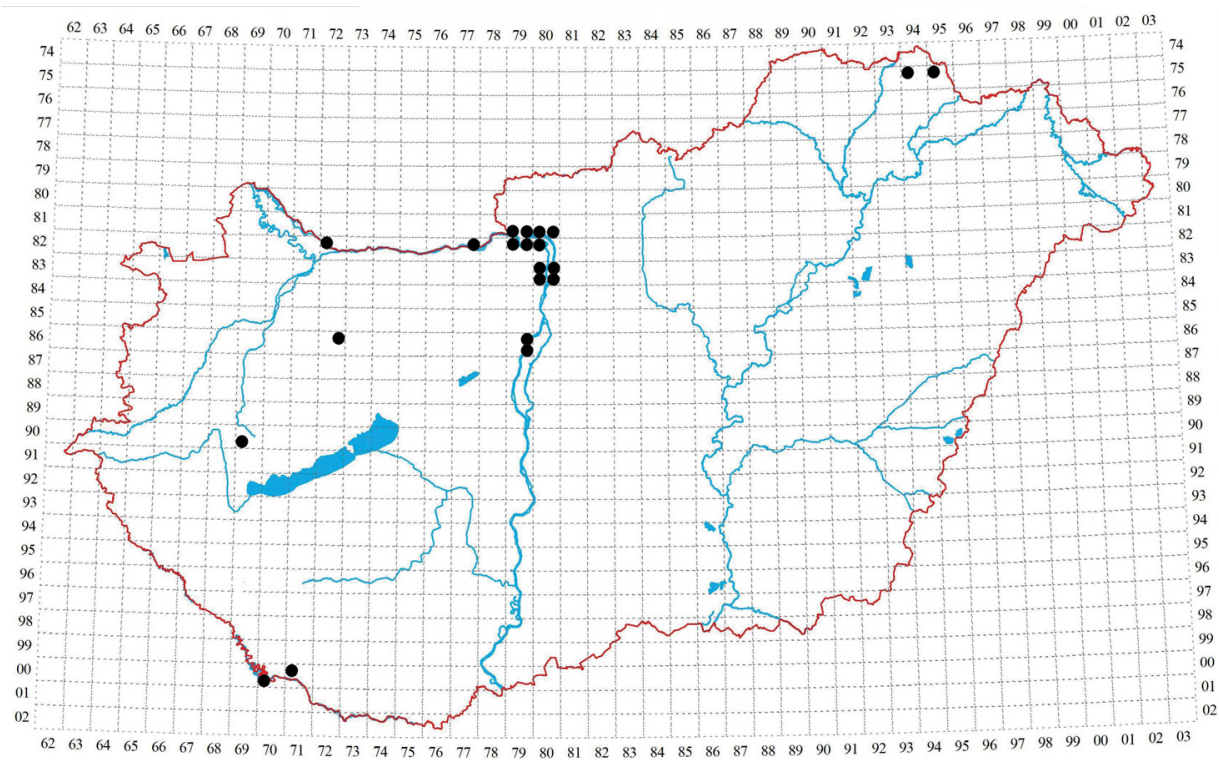

Fig. 12. Records of Riccia bifurca. 
ma patens, Riccia glauca. - [8380.3] Pest county, island of Szentendre at Szigetmonostor, on drying mud at the western bank of the island, south of the ferry to Szentendre old town, $47.64542^{\circ} \mathrm{N}$, $19.07992^{\circ}$ E, 100 m; leg. P. Erzberger, 22.10.2015, B-Erzberger 20899/A, 20901. Associated bryophytes: Aphanorrhegma patens, Riccia glauca, R. frostii, Physcomitrium eurystomum. - [8380.4] Pest county, island of Szentendre at Szigetmonostor, on drying mud at the western bank of the island, south of the ferry to Szentendre old town, $47.63833^{\circ} \mathrm{N}, 19.08675^{\circ} \mathrm{E}$, and $47.62942^{\circ} \mathrm{N}, 19.09186^{\circ} \mathrm{E}$, 100 m; leg. P. Erzberger, 22.10.2015, B-Erzberger 20910/C. Associated bryophytes: Aphanorrhegma patens, Riccia glauca, $R$. cavernosa, R. frostii, Physcomitrium eurystomum. - [8679.2] Pest county, island of Csepel, $\mathrm{W}$ of the village of Halásztelek, on drying mud, $47.38097^{\circ} \mathrm{N}, 18.97897^{\circ} \mathrm{E}$, and $47.36908^{\circ} \mathrm{N}, 18.96208^{\circ}$ E, 95 m; leg. P. Erzberger, 03.11.2015, B-Erzberger 21024, 21034. Associated bryophytes: Riccia glauca, Bryum klinggraeffi. - [8679.4] Pest county, island of Csepel, NW of the village of Tököl, on drying mud, $47.34889^{\circ} \mathrm{N}, 18.95181^{\circ} \mathrm{E}, 95 \mathrm{~m}$; leg. P. Erzberger, 03.11.2015, B-Erzberger 21037. Associated bryophyte: Aphanorrhegma patens. - Dráva-sík - [0070.3] Baranya county, small island in river Dráva near the town of Barcs, on drying mud, $45.93919^{\circ} \mathrm{N}, 17.40400^{\circ}$ E, $100 \mathrm{~m}$; leg. A. Mesterházy, Cs. Németh and P. Erzberger, 30.09.2015, B-Erzberger 20657. Associated bryophytes: Aphanorrhegma patens, Riccia glauca. - [0071.1] Baranya county, beside temporary pool in lucerne field NE of the town of Barcs, $45.99333^{\circ} \mathrm{N}, 17.52167^{\circ} \mathrm{E}, 125 \mathrm{~m}$; leg. A. Mesterházy, 04.05.2015, HCsN 6657; and leg. A. Mesterházy and Cs. Németh, 18.05.2015, HCsN 6680 (det. P. Erzberger). Associated bryophytes: Bruchia flexuosa (Schwägr.) Müll. Hal. (MesterhÁzy and NÉmetr 2015), Dicranella staphylina, Anthoceros agrestis Paton, Phaeoceros carolinianus, Bryum bicolor, B. argenteum, Physcomitrium pyriforme, Ceratodon purpureus, Funaria hygrometrica Hedw., Ditrichum cylindricum. - Keszthely Mts - [9069.3] Zala county, Kovácsi Hill, near Zalaszántó, on moist forest road over basaltic bedrock, $46.91350^{\circ} \mathrm{N}, 17.18153^{\circ} \mathrm{E}, 335 \mathrm{~m}$; leg. P. Erzberger and Cs. Németh, 28.06.2013, B-Erzberger 16458, 16459 as $R$. glauca var. subinermis (rev. L. Meinunger and W. Schröder). Associated bryophytes: Riccia sorocarpa, Ditrichum cylindricum (Hedw.) Grout, Bryum rubens, Pohlia lutescens. - Zemplén Mts - [7594.1] Borsod-Abaúj-Zemplén county, Ósva Stream Valley S of Telkibánya, Csemetekert, on soil, $48.46486^{\circ} \mathrm{N}, 21.38842^{\circ} \mathrm{E}$, 365 m; leg. P. Erzberger and B. Papp, 16.04.2006, B-Erzberger 11435 (det. P. Erzberger, conf. W. Schröder and L. Meinunger 2015). Associated bryophytes: Ephemerum minutissimum, Pottia truncata (Hedw.) Bruch et Schimp., Bryum bicolor, B. violaceum, Leptodictyum riparium, Phascum cuspidatum var. cuspidatum. - [7595.1] Borsod-Abaúj-Zemplén county, on soil in fallow field $\mathrm{E}$ of Pálháza, $48.47336^{\circ} \mathrm{N}, 21.54519^{\circ}$ E, $150 \mathrm{~m}$; leg. P. Erzberger and B. Papp, 15.04.2006, B-Erzberger 11416 as R. glauca L. (rev. W. Schröder 2015). Associated bryophytes: Pottia truncata, Ephemerum minutissimum, Bryum klinggraeffi Schimp., B. bicolor Dicks., Dicranella staphylina H. Whitehouse, Riccia sorocarpa Bisch., Phaeoceros carolinianus (Michx.) Proskauer.

Boros (1968) reported this species from several mountain regions, among them the Zemplén Mts, and lowland areas, in particular along the rivers Dráva, Tisza and Maros. The extensive stands along the Danube are reported here for the first time.

In the recent past, $R$. bifurca seems to have been overlooked as $R$. glauca, with which it shares not only a morphological similarity, but also its lowland habitat along great rivers. Both species have a rather wide thallus with a \pm flat groove. However, in R. glauca, the thallus is 3-5 times wider than high (seen in transverse section), with sharp, \pm deflexed margins, whereas the thallus of $R$. bifurca is only up to 3(-4) times as wide as high, and has a raised, convex margin forming small tumid ridges. The spores of $R$. bifurca are light brown and translucent even when 
old, 60-85(-90) $\mu \mathrm{m}$ in diameter, with 6-7(-8) closed alveoles 9-13 $\mu \mathrm{m}$ wide on the distal face and mostly no closed alveoles on the proximal faces, whereas the spores of $R$. glauca are darker red brown to brown, blackish when old, opaque to hardly translucent (but light brown translucent when just ripe), 80-100 $\mu \mathrm{m}$ in diameter, with 6-8(-12) alveoles 6-12 $\mu \mathrm{m}$ wide on the distal face and usually well delimited alveoles on the proximal faces.

The authors followed the concept of Jovet-Ast (1986) and DAMSHolT (2002) during the identification of species instead of PATON (1999), for details of the discrepancies see MEINUNGER and SCHRÖDER (2007).

\section{Riccia frostii Austin}

(Figs 13-14)

Amended red list status: NT, also protected by law (MK 2012). Candidate for new European red list (Hodget Ts 2015); ECCB (1995): R.

Danube inundation area - [8171.3] Györ-Moson-Sopron county, Szigetköz, Danube bank near Ásványráró, on drying mud, $47.81542^{\circ} \mathrm{N}, 17.56458^{\circ} \mathrm{E}, 115 \mathrm{~m}$; obs. Cs. Németh and P. Erzberger, 04.10.2015. Associated bryophytes: Aphanorrhegma patens, Riccia glauca. - [8178.4] Komárom-Esztergom county, Danube bank at Esztergom-Búbánatvölgy, on drying mud, $47.81397^{\circ}$ $\mathrm{N}, 18.81611^{\circ} \mathrm{E}, 113 \mathrm{~m}$; leg. P. Erzberger, 21.09.2015, B-Erzberger 20561. Associated bryophytes: Aphanorrhegma patens, Riccia cavernosa Hoffm. emend. Raddi, Ricciocarpos natans. - [8179.3] Komárom-Esztergom county, Danube bank at Pilismarót-Basaharc, near the ferry to Szob, on drying mud, $47.80994^{\circ} \mathrm{N}, 18.87142^{\circ} \mathrm{E}, 105 \mathrm{~m}$; leg. P. Erzberger, 23.09.2015, B-Erzberger 20612. Associated bryophytes: Aphanorrhegma patens, Riccia cavernosa, R. bifurca. - [8179.4] Pest county, Danube bank on island of Szentendre at Kisoroszi near Szigetcsúcs, on drying mud, $47.80672^{\circ} \mathrm{N}$, $18.98942^{\circ}$ E, $100 \mathrm{~m}$; leg. P. Erzberger, 28.09.2015, B-Erzberger 20631. Associated bryophytes: Aphanorrhegma patens, Riccia cavernosa, R. bifurca. - [8180.3] Pest county, northern Danube bank on island of Szentendre at Kisoroszi, on drying mud, $47.81422^{\circ} \mathrm{N}, 19.01644^{\circ} \mathrm{E}, 100 \mathrm{~m}$; leg. P. Erzberger, 01.10.2015, B-Erzberger 20655. Associated bryophytes: Aphanorrhegma patens, Physcomitrium eurystomum Sendtn. - [8180.4] Pest county, on the island of Szentendre between Tahitótfalu and Kisoroszi, Danube bank opposite the cement factory of Vác, on drying mud, $47.80014^{\circ} \mathrm{N}$, $19.08539^{\circ}$ E, 100 m; leg. P. Erzberger, 02.10.2015, B-Erzberger 20682/A. Associated bryophytes: Aphanorrhegma patens, Riccia cavernosa, R. bifurca, R. glauca. - [8272.1] Györ-Moson-Sopron county, Szigetköz, Danube bank at Nagybajcs, on drying mud, $47.76811^{\circ} \mathrm{N}, 17.69322^{\circ} \mathrm{E}, 115 \mathrm{~m}$; leg. Cs. Németh and P. Erzberger, 04.10.2015, B-Erzberger 20691, HCsN 7336. Associated bryophyte: Aphanorrhegma patens. - [8272.3] Győr-Moson-Sopron county, Szigetköz, Danube bank at Vének, on drying mud, $47.74864^{\circ} \mathrm{N}, 17.74072^{\circ} \mathrm{E}, 110 \mathrm{~m}$; leg. Cs. Németh, 02.10.2015 (Fig. 13), HCsN 7333. Associated bryophytes: Aphanorrhegma patens, Riccia cavernosa. - [8273.3] GyörMoson-Sopron county, Danube bank at Gönyü, on drying mud, $47.73978^{\circ} \mathrm{N}, 17.84083^{\circ} \mathrm{E}, 110 \mathrm{~m}$; leg. Cs. Németh, 02.10.2015, HCsN 7327. Associated bryophytes: Aphanorrhegma patens, Riccia cavernosa. - [8274.1] Komárom-Esztergom county, Szent Pál-sziget at Komárom-Koppánymonostor, Danube bank, on drying mud, $47.75128^{\circ} \mathrm{N}, 18.02464^{\circ} \mathrm{E}, 110 \mathrm{~m}$; leg. Cs. Németh, 24.09.2015, HCsN 7296. Associated bryophytes: Aphanorrhegma patens, Riccia cavernosa, Ricciocarpos natans. - [8275.3] Komárom-Esztergom county, Szőnyi-sziget at Komárom-Szőny, Danube bank, on drying mud, $47.73636^{\circ} \mathrm{N}, 18.17792^{\circ} \mathrm{E}, 110 \mathrm{~m}$; leg. Cs. Németh, 24.09.2015, HCsN 7301. Associated bryophytes: Aphanorrhegma patens, Riccia cavernosa, R. glauca. - [8276.3] Komárom-Esztergom 
county, Danube bank at Neszmély near Alsó-sziget, on drying mud, $47.74475^{\circ} \mathrm{N}, 18.40150^{\circ} \mathrm{E}$, $110 \mathrm{~m}$; leg. Cs. Németh and P. Erzberger, 22.09.2015, B-Erzberger 20602, HCsN 7286. Associated bryophyte: Aphanorrhegma patens. - [8277.2] Komárom-Esztergom county, Danube bank at Tát near the cemetery, on drying mud, $47.75319^{\circ} \mathrm{N}, 18.62597^{\circ} \mathrm{E}, 105 \mathrm{~m}$; leg. Cs. Németh and P. Erzberger, 22.09.2015, B-Erzberger 20594, HCsN 7275. Associated bryophytes: Aphanorrhegma patens, Riccia bifurca. - [8279.1] Komárom-Esztergom county, Danube bank north of Dömös, on drying mud, $47.77536^{\circ} \mathrm{N}, 18.90581^{\circ} \mathrm{E}$, and $47.77897^{\circ} \mathrm{N}, 18.90472^{\circ} \mathrm{E}, 100 \mathrm{~m}$; leg. P. Erzberger,

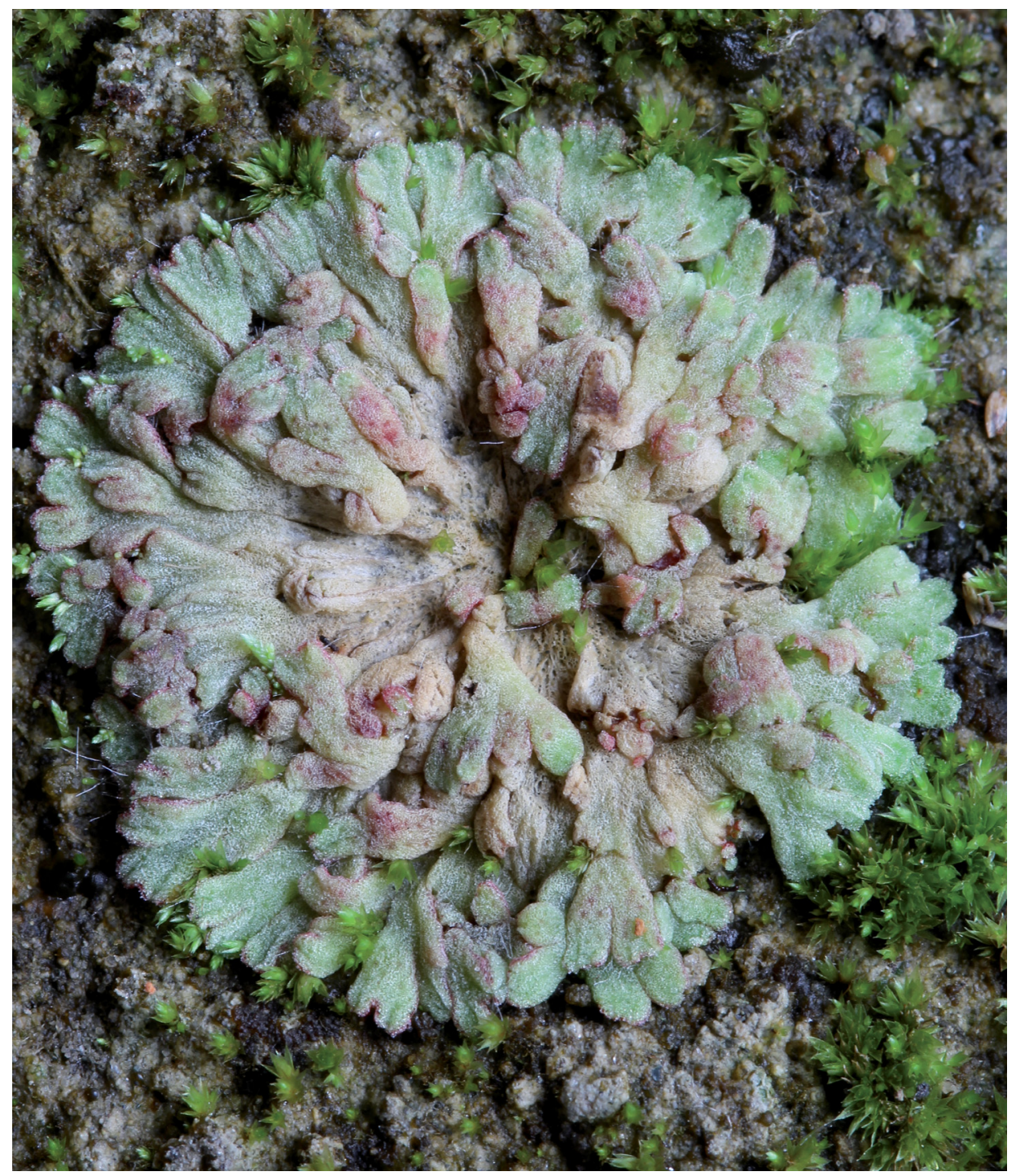

Fig. 13. Riccia frostii, Szigetköz, Vének, Danube bank (photo: Cs. Németh, 02.10.2015 [8272.3]). 
28.10.2015, B-Erzberger 20962/A, 20963, 20964/A. Associated bryophytes: Riccia cavernosa, $R$. bifurca, Aphanorrhegma patens, Marchantia polymorpha L. subsp. ruderalis Bischl. et Boisselier. - [8279.2] Pest county, Danube bank east of Dömös, on drying mud, $47.76128^{\circ} \mathrm{N}, 18.93567^{\circ} \mathrm{E}$, 100 m; leg. P. Erzberger, 23.09.2015, B-Erzberger 20618. Associated bryophytes: Aphanorrhegma patens, Riccia bifurca, R. cavernosa. - [8280.1] Pest county, island of Szentendre at Tahitótfalu, Danube bank near Kecske-zátony, on drying mud, $47.76372^{\circ} \mathrm{N}, 19.07594^{\circ} \mathrm{E}, 105 \mathrm{~m}$; leg. P. Erzberger, 23.09.2015, B-Erzberger 20625. Associated bryophytes: Aphanorrhegma patens, Riccia bifurca, $R$. cavernosa. - [8280.2] Pest county, eastern Danube bank on island of Szentendre at Tahitótfalu north of the ferry to Vác, on drying mud, $47.78961^{\circ} \mathrm{N}, 19.10303^{\circ} \mathrm{E}, 100 \mathrm{~m}$; leg. P. Erzberger, 01.10.2015, B-Erzberger 20669. Associated bryophyte: Aphanorrhegma patens. - [8280.4] Pest county, island of Szentendre at Szigetmonostor, western bank of the island, south of the ferry to Szentendre-Határcsárda, on drying mud at the riverbank, $47.70239^{\circ} \mathrm{N}, 19.09250^{\circ} \mathrm{E}, 110 \mathrm{~m}$; leg. P. Erzberger, 18.10.2015, B-Erzberger 20876. Associated bryophytes: Riccia glauca, Aphanorrhegma patens. - [8380.1] Pest county, island of Szentendre at Szigetmonostor, on drying mud at the western bank of the island, south of the ferry to Szentendre old town, $47.65367^{\circ} \mathrm{N}, 19.08086^{\circ}$ E, 100 m; leg. P. Erzberger, 22.10.2015, B-Erzberger 20894. Associated bryophytes: Aphanorrhegma patens, Riccia cavernosa, R. glauca, R. bifurca. - [8380.2] Pest county, island of Szentendre at Szigetmonostor, western bank of the island, south of the ferry to Szentendre-Határcsárda, on drying mud at the riverbank, $47.68203^{\circ} \mathrm{N}, 19.08856^{\circ} \mathrm{E}, 100 \mathrm{~m}$; leg. P. Erzberger, 18.10.2015, BErzberger 20885. Associated bryophyte: Aphanorrhegma patens. - [8380.3] Pest county, island of Szentendre at Szigetmonostor, on drying mud at the western bank of the island, south of the ferry to Szentendre old town, $47.64542^{\circ} \mathrm{N}, 19.07992^{\circ} \mathrm{E}, 100 \mathrm{~m}$; leg. P. Erzberger, 22.10.2015, BErzberger 20898, 20899, 20902. Associated bryophytes: Aphanorrhegma patens, Riccia glauca, $R$. cavernosa, R. bifurca, Physcomitrium eurystomum. - [8380.4] Pest county, island of Szentendre at Szigetmonostor, on drying mud at the western bank of the island, south of the ferry to Szentendre old town, $47.63833^{\circ} \mathrm{N}, 19.08675^{\circ} \mathrm{E}$, and $47.62942^{\circ} \mathrm{N}, 19.09186^{\circ} \mathrm{E}, 100 \mathrm{~m}$; leg. P. Erzberger,

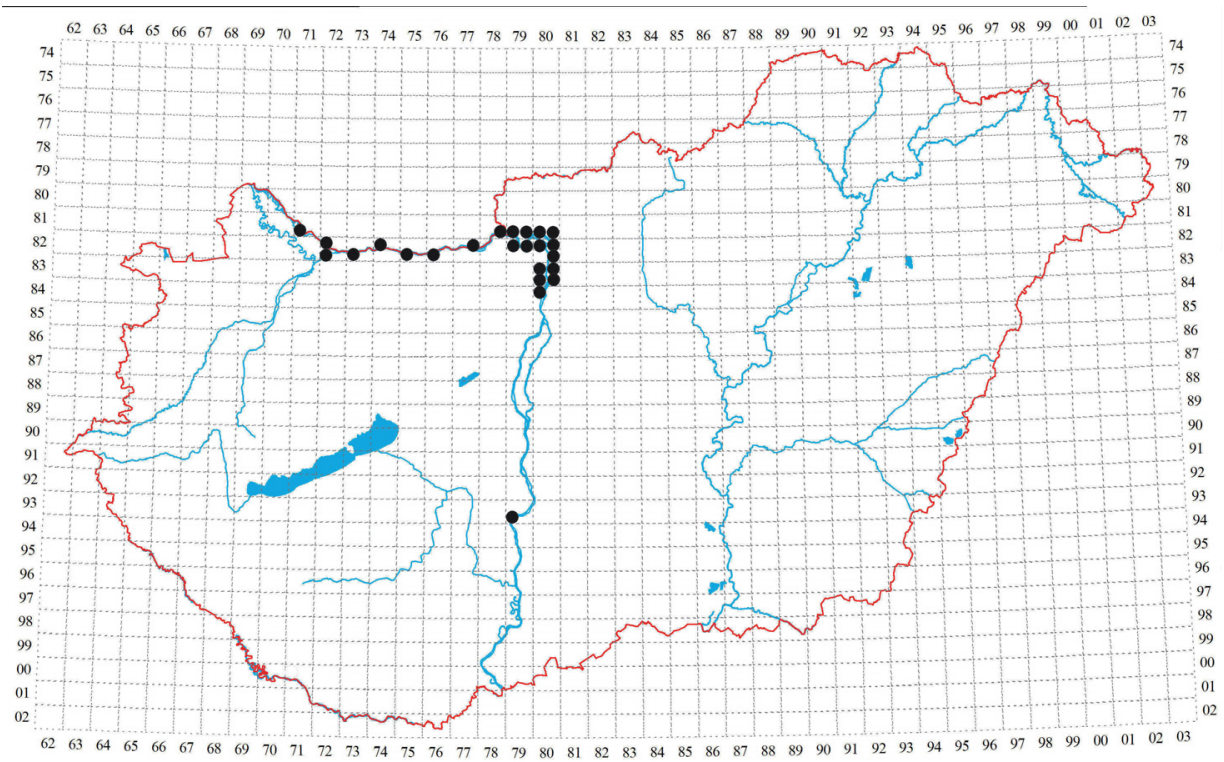

Fig. 14. Records of Riccia frostii. 
22.10.2015, B-Erzberger 20910, 20913. Associated bryophytes: Aphanorrhegma patens, Riccia glauca, R. cavernosa, Physcomitrium eurystomum. - [8480.1] Pest county, island of Szentendre at Szigetmonostor, on drying mud at the western bank near the south end of the island, $47.59897^{\circ} \mathrm{N}$, $19.07372^{\circ}$ E, 100 m; leg. P. Erzberger, 22.10.2015, B-Erzberger 20914/C. Associated bryophytes: Aphanorrhegma patens, Riccia glauca, R. cavernosa, Ricciocarpos natans. - [9379.3] Tolna county, small backwater near Danube bank at Paks, on drying mud, $46.63581^{\circ} \mathrm{N}, 18.87814^{\circ} \mathrm{E}, 90 \mathrm{~m}$; leg. P. Erzberger, 14.10.2015, B-Erzberger 20848. Associated bryophytes: Aphanorrhegma patens, Riccia glauca, $R$. cavernosa, Ricciocarpos natans.

In favourable years, after a warm and dry summer, when the water table of rivers is low, this species can colonise in autumn very many sites on drying mud in the bed of great rivers, its exclusive habitat, as it was already observed by Boros (1968). Since it may be absent during other times, it may appear rarer than it is in fact, since obviously its spores are present in the sediments of the river bed. However, Boros (1968) observed the species only downward from Zebegény at the Danube, and in addition at the rivers Tisza and Maros. The occurrences in Szigetköz and in the interval between Gönyü and Tát have not been reported before.

When sporophytes are present, the small spore size $(40-65 \mu \mathrm{m})$ makes the determination of this species easy. Once recognised, the fan-shaped large (ca 2 $\mathrm{cm}$ ) rosettes usually tinged with pink are very characteristic.

Riccia huebeneriana Lindenb.

(Fig. 15)

Amended red list status: EN, also protected by law (MK 2012). Candidate for new European red list (Hodget Ts 2015); ECCB (1995): R.

Kemeneshát - [8967.1] Vas county, on nutrient-rich, wet ground surface of Carex elata All. - Salix cinerea L. plant community near Alsóújlak (Jelihálás), $47.06444^{\circ} \mathrm{N}, 16.88833^{\circ} \mathrm{E}, 235$ m; leg. A. Mesterházy, 15.07.2015, HCsN 7172 (det. Cs. Németh, conf. P. Erzberger). Associated bryophyte: Riccia fluitans L. emend. Lorb. - Dráva sík - [0071.1] Somogy county, Juniperetum "Ösborókás" near the town of Barcs, on moist soil in Caricetum, $45.99075^{\circ} \mathrm{N}, 17.55444^{\circ} \mathrm{E}, 125$ m; leg. P. Erzberger, B. Papp and E. Szurdoki, 10.10.2013, B-Erzberger 16805, BP 52033/H (det. P. Erzberger, conf. W. Schröder and L. Meinunger); associated bryophytes: Riccia fluitans, R. glauca; and moorland Nagyberek near Darány, $45.98622^{\circ} \mathrm{N}, 17.55753^{\circ} \mathrm{E}, 125 \mathrm{~m}$; leg. A. Mesterházy, Cs. Németh and P. Erzberger, 30.09.2015 (Fig. 15), B-Erzberger 20647, HCsN 7317.

Boros (1968) reported the species from three regions: Vasi-Hegyhát, Belső-Somogy (possibly the above-mentioned sites), and Örség. Interestingly, he did not find any sporophytes, whereas in our collections capsules are present.

This species belongs to subgenus Ricciella, sect. Spongodes (together with $R$. cavernosa, $R$. crystallina auct. medio-eur. non L. emend. Raddi, and $R$. frostii), characterised by a \pm spongy upper thallus surface (most distinct in $R$. caverno$s a$ ), but in $R$. huebeneriana the surface becomes lacunose only in older parts of the thallus. The thallus lobes of $R$. huebeneriana are linear even when adult (1-3 
$\mathrm{mm}$ long, $0.5-0.8 \mathrm{~mm}$ wide), and often tinged violet. Capsules are frequent, and prominent on the ventral (lower) side of the thallus. Spores are yellowish-brown with dark ornamentation, 60-72(-95) $\mu \mathrm{m}$ in diameter, with 6-7 completely delimited alveoles across the distal face.

\section{Riccia subbifurca Warnst.}

Amended red list status: EN.

Vértes Mts - [8676.3] Fejér county, Kölik near Bucka Hill in the vicinity of the village Csákberény, calcareous grassland, $47.34456^{\circ} \mathrm{N}, 18.35278^{\circ} \mathrm{E}, 210 \mathrm{~m}$; leg. P. Erzberger, 12.04 .2004 and 12.03.2015, B-Erzberger 9980 (det. P. Erzberger, conf. L. Meinunger and W. Schröder, 12.03.2015). Associated bryophytes: Riccia sorocarpa, R. ciliifera Link ex Lindenb., Athalamia hyalina (Sommerf.) S. Hatt., Phascum curvicolle, Pottia mutica. - Mezöföld-Sárrét - [8975.2] Fejér county, Köszárhegy near Polgárdi, calcareous grassland above steep rock wall of limestone quarry, $47.09197^{\circ} \mathrm{N}, 18.31797^{\circ}$ E, $198 \mathrm{~m}$; leg. P. Erzberger and T. Pócs, 26.09.2014, B-Erzberger 18895 as $R$. cf. sorocarpa var. heegii Schiffn. (rev. L. Meinunger and W. Schröder, 02.2015). Associated bryophytes: $R$. sorocarpa, Acaulon triquetrum, Didymodon acutus (Brid.) K. Saito.

It is reported in Boros (1968) from only two sites in the Visegrád and Buda Mts, but revision of specimens is desirable.

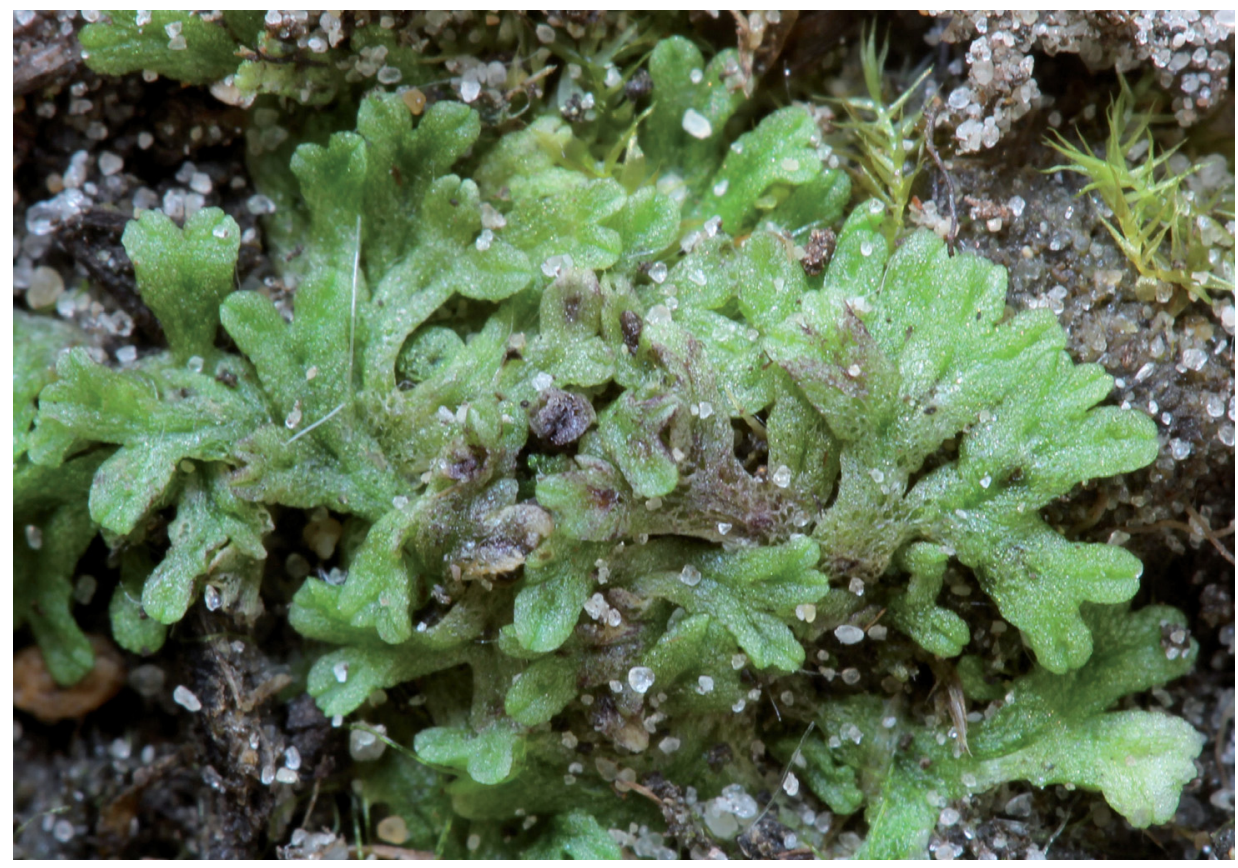

Fig. 15. Riccia huebeneriana, Dráva-sík, Darány (photo: Cs. Németh, 30.09.2015 [0071.1]). 
This species is characterised by brown to dark brown, rather large spores, 80-100 $\mu \mathrm{m}$; with closed alveoles on the proximal face ( $R$. bifurca: spores 60-85$(-90) \mu \mathrm{m}$; alveoles mostly indistinct on proximal face) and 8-12 alveoles across the distal face ( $R$. bifurca: with 6-7(-8) alveoles across the distal face). Cilia, papillose in their upper part, 70-120(-200) $\mu \mathrm{m}$ long, are frequently found near the thallus margin (in $R$. bifurca, smooth cilia, 120-340 $\mu \mathrm{m}$ long, may be sometimes found).

\section{Seligeria campylopoda Kindb.}

(Fig. 16)

Amended red list status: CR. Candidate for new European red list (HodgetTs 2015).

Keszthely Mts - [9169.3] Zala county, Csóka-kő dolomitic rock group north of the village of Rezi, on small dolomitic stones lying loose on the ground of shady northern steep slope in CornoQuercetum forest, $46.81722^{\circ} \mathrm{N}, 17.23806^{\circ} \mathrm{E}, 250 \mathrm{~m}$; leg. P. Erzberger, Cs. Németh, B. Papp and A. Kovács, 24.10.2015 (Fig. 16), B-Erzberger 20945, 20947, HCsN 7366. Associated bryophyte: Tortella tortuosa (Hedw.) Limpr. juv.

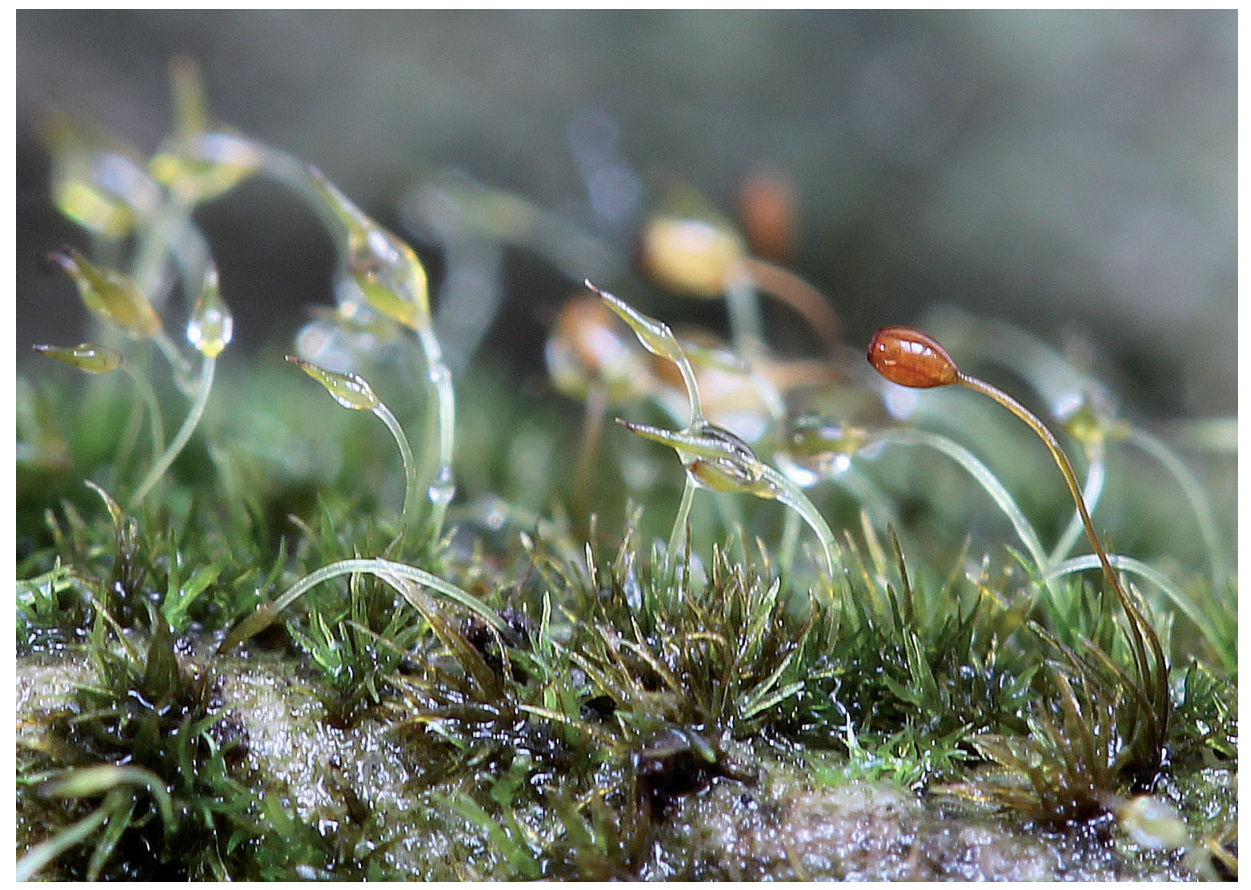

Fig. 16. Seligeria campylopoda, Keszthely Mts, Keszthely, Csóka-kő (photo: Cs. Németh, 24.10.2015 [9169.3]). 
It was first collected in this site by Boros and Vajda in 1963 as S. pusilla (also in Boros 1968), and revised by Gos and OCHYRA (1994) (ERzBERGER and PAPP 2004). From $S$. recurvata, which also has a curved seta (when moist, flexuose or straight when dry) this species is distinguished by the leaf lamina running up nearly to the apex, whereas in $S$. recurvata the upper part of the leaf is filled completely by the costa. The latter species usually occurs in protected crevices of siliceous rocks, whereas $S$. campylopoda is found on dolomitic pebbles.

Seligeria trifaria (Brid.) Lindb. var. longifolia (Broth.) Ochyra et Gos

Amended red list status: CR. Candidate for new European red list (HoDGETTS 2015).

Bükk Mts - [7989.4] Borsod-Abaúj-Zemplén county, Fátyol Waterfall (Szinva-vízesés) at Miskolc-Lillafüred, in wet limestone cavity under overhanging rock in the spray-zone of the waterfall, $48.10469^{\circ} \mathrm{N}, 20.62436^{\circ} \mathrm{E}, 300 \mathrm{~m}$; leg. Cs. Németh, A. Mesterházy, A. Schmotzer, V. G. Papp, 08.10.2014, HCsN 6332 (det. Cs. Németh, conf. P. Erzberger,). Associated bryophyte: Eucladium verticillatum.

This species has previously been observed only once in Hungary. Voucher specimens collected in Eger in 1962 and determined by L. Vajda as Seligeria pusilla are deposited in BP and EGR. Material from the former collection (BP 75532) was revised by Gos in 1991 as S. trifaria var. longifolia (ERzBERGER and PAPP 2004).

Syntrichia caninervis Mitt. var. gypsophila (J. J. Amann ex G. Roth) Ochyra (syn. Tortula caninervis (Mitt.) Broth. subsp. spuria (J. J. Amann) W. A. Kramer)

Amended red list status: $\mathrm{DD}$ (IUCN).

Danube-Tisza Interfluve - [8980.2] Bács-Kiskun county, saline grassland near the road south of the village Apaj, $47.08647^{\circ} \mathrm{N}, 19.09817^{\circ} \mathrm{E}, 95 \mathrm{~m}$; leg. P. Erzberger, accompanied by B. Papp and E. Szurdoki, 12.04.2006, B-Erzberger 11395 (det. P. Erzberger 02.2015).

Tóтн $(1986,1987)$ first demonstrated the presence of this species (as Tortula caninervis subsp. spuria (J. J. Amann) W. A. Kramer) in the Hungarian bryoflora by revision of 4 herbarium specimens, collected by Boros in the Danube-Tisza Interfluve between 1926 and 1959: [8685.3] Tápiószele: Papszög, 1958 (BP 108603); [8980.4] Kunszentmiklós, 1926 (BP 108582); [9181.1] Szabadszállás: Öregbucka, 1951 (BP 108609); [9683.4] Kiskunhalas: Bodoglári-erdő, 1959 (BP 108605).

This species is characterised by a partially bistratose leaf lamina and very conspicuous high, branched papillae on the abaxial side of the costa, visible with a hand lens. It is probably often overlooked due to its similarity to the common $S$. ruralis occurring in the same habitat. 


\section{Syntrichia laevipila Brid.}

Amended red list status: DD(IUCN).

Bükk Mts - [8087.2] Heves county, southern slope of Vár-hill at Szarvaskő, on gabbro, leg. P. Erzberger and T. Pócs, 23.04.1998, B-Erzberger 4434. - [8089.1] Borsod-Abaúj-Zemplén county, Kis-Piliske thermophilic oak forest above Hór Valley north of the village Cserépfalu, on the bark of Quercus, $47.97011^{\circ} \mathrm{N}, 20.53533^{\circ} \mathrm{E}, 420 \mathrm{~m}$; leg. P. Erzberger, accompanied by P. Ódor and B. Papp, 18.06.2012, B-Erzberger 15334 (det. P. Erzberger, conf. U. Abts). - Mecsek Mts - [9874.3] Baranya county, near the road between Bükkösd and Hetvehely, roadside with limestone rock outcrops, $46.12733^{\circ} \mathrm{N}, 18.03094^{\circ} \mathrm{E}, 170 \mathrm{~m}$; leg. P. Erzberger, accompanied by D. Kovács and J. Deme, 14.10.2015, B-Erzberger 20830. Associated bryophytes: Didymodon acutus, Syntrichia ruralis.

Boros (1968) reported this preferentially corticolous species from many regions throughout the country. It seems to be under-recorded at present due to similarity with other members of the genus.

Syntrichia laevipila is characterised by a (nearly) smooth hair point and the lack of papillae on the abaxial side of the costa. Vegetative propagules in the form of minute leaves are sometimes produced (e.g. observed in the specimen from Szarvaskő).

\section{Ulota coarctata (P. Beauv.) Hammar}

Amended red list status: CR.

Örség - [9065.3] Vas county, in Alnus glutinosa (L.) Gaertn. woodland along stream north of the village Szöce, on a thin stem of Prunus padus L., $46.90069^{\circ} \mathrm{N}, 16.57225^{\circ} \mathrm{E}, 230 \mathrm{~m}$; leg. K. Baráth and P. Erzberger, 13.08.2015, B-Erzberger 20437 (det. P. Erzberger). Associated bryophytes: Orthotrichum spp., Ulota crispa (Hedw.) Brid.

Boros (1968) reported this rare species from 7 locations, among them Vendvidék not far from the site reported here.

Ulota coarctata is immediately recognised by the characteristically pearshaped capsule contracted with short striae around the mouth.

\section{CONCLUSIONS}

In this paper we report new occurrences of 37 species that were previously without recent data (in the categories RE, DD-va and DD) in Hungary. According to the present state of knowledge, of these 37 species 10 are critically endangered (Brachythecium geheebii, Bryum funckii, Fontinalis hypnoides, Jungermannia atrovirens, Poblia proligera, Riccardia chamedryfolia, Seligeria campylopoda, S. trifaria var. longifolia, Ulota coarctata, Ulota hutchinsiae), 14 are endangered (Bryum creberrimum, B. gemmilucens, B. mildeanum, B. pallescens, B. turbinatum, Campylopus pyriformis, Leiocolea badensis, Lophozia sudetica, Philonotis calcarea, P. marchica, Pohlia annotina, Racomitrium affine, Riccia huebeneriana, R. subbifurca), 2 are vulnerable (Fossombronia wondraczekii, Isopterygiopsis pulchella) and 5 are near threat- 
ened (Conardia compacta, Fissidens gymnandrus, Pellia epiphylla, Riccia bifurca, $R$. frostii). For 6 species, in spite of the new occurrences, data are insufficient to assign a red list status, therefore these are rated $\mathrm{DD}(\mathrm{IUCN})$, a modified definition of data deficient. These are: Brachythecium capillaceum, Bryum intermedium, Cephaloziella hampeana, Cinclidotus danubicus, Syntrichia caninervis var. gypsophila, S. laevipila.

Table 1 gives an overview of the changes and the data on which they are based.

In the latest red list (PAPP et al. 2010), the authors stated a high percentage of taxa without recent data (21.1\%), and assumed that some or many of them might have disappeared from Hungary, in particular those labelled DD-va. It is therefore fortunate that we can report here extant populations of 37 taxa that were without recent data, among them four species that had been searched in vain at their old localities, and even one that was thought to be regionally extinct. The resulting percentage of $15.6 \%$ of taxa without recent data is still high, compared with that of countries like e.g. Sweden (3.5\%) or Switzerland (9\%), but comparable to that of the Czech Republic (16.2\%) or the Iberian Peninsula (14.8\%) (PAPP et al. 2010). Hopefully, during ongoing field studies, this percentage can still be lowered.

There is no simple explanation of why the species reported here were without recent data. At least for those that were widespread in the past and are not rare at present, we had to learn anew what our "ancestors" knew already. There is an unfortunate gap in Hungarian bryological field and collecting activity between ca 1975 and 1985, as experienced during revisionary studies of some genera (e.g. Bryum) and documented in some members of the Grimmiaceae (ERZBERGER and SCHRÖDER 2008: Fig. 2). Thus, knowledge of certain species may not have been passed on to the next generation of bryologists. In the present account this is most convincingly documented in the cases of Riccia bifurca and R. frostii. This paper therefore also aims at improving knowledge of the species by giving some details of their ecology and morphology, including photographs, in the hope that at least for these species, new occurrences will be found.

Acknowledgements - We thank N. Békefi, J. Deme, A. Kovács, D. Kovács, G. Mészáros, J. Nagy, K. Nagy, P. Ódor, M. Óvári, V. G. Papp, T. Pócs, A. Rigó, D. Schmidt, A. Schmotzer, and E. Szurdoki for guidance and support in the field, and contributing unpublished data, often from excursions with the authors, for this survey. We are also grateful to H. Bednarek-Ochyra (Krakow, Poland), W. Schröder and L. Meinunger (Ludwigsstadt, Germany), U. Abts (Krefeld, Germany) and J. Váňa (Prague, Czech Republic), for examining specimens of critical taxa.

Összefoglaló: A fajlisták és vörös listák törvényszerű sorsa, hogy már szinte megjelenésük pillanatában elavulttá válnak. A legutolsó, Magyarország moháit tartalmazó vörös lista 5 évvel ezelőtt jelent meg nyomtatásban. Köszönhetően azonban mindenekelőtt az elmúlt időszak szisztematikus kvadrát alapú térképezéseinek, valamint a komplikáltabb rendszertani csoportokat érintő herbáriu- 


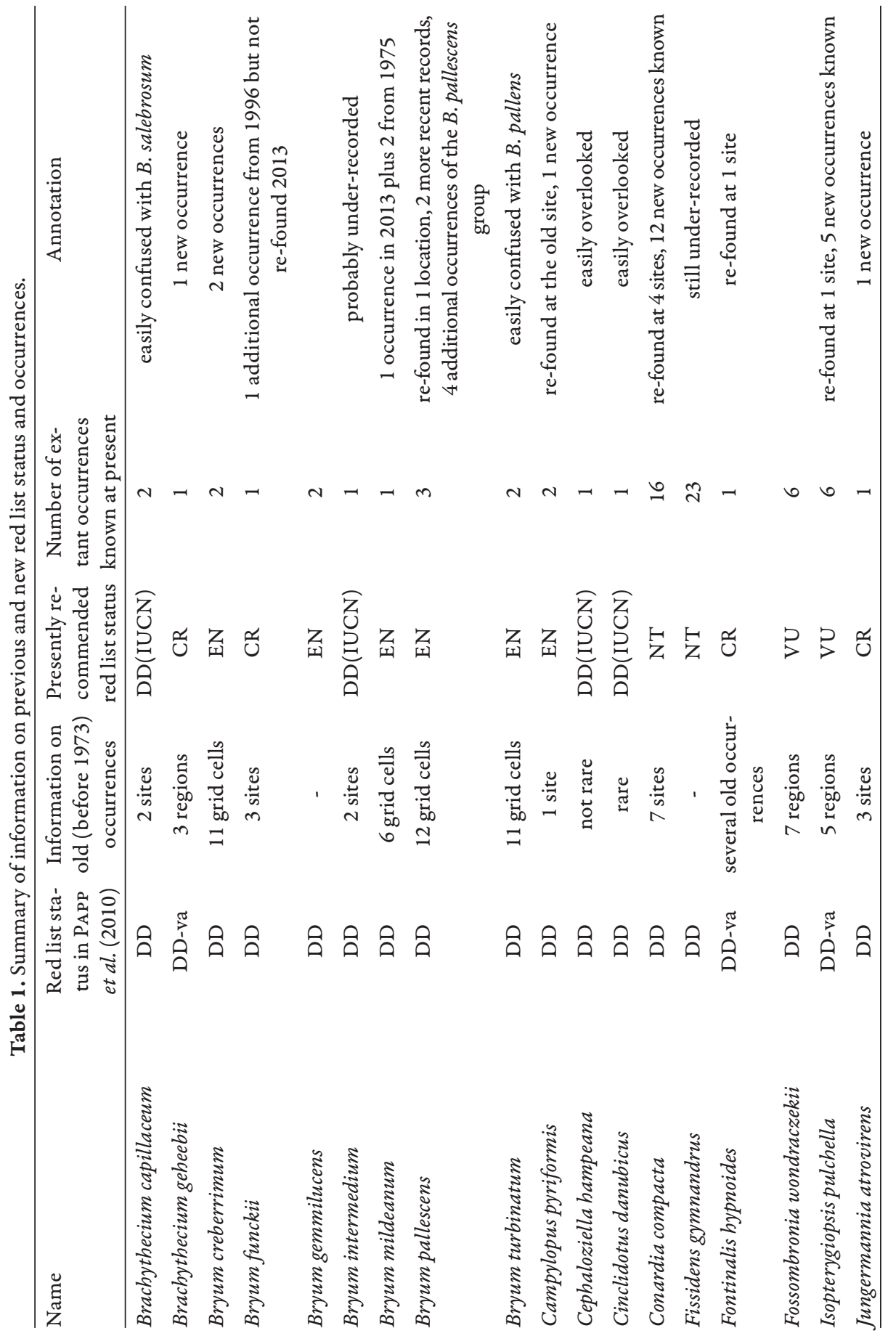




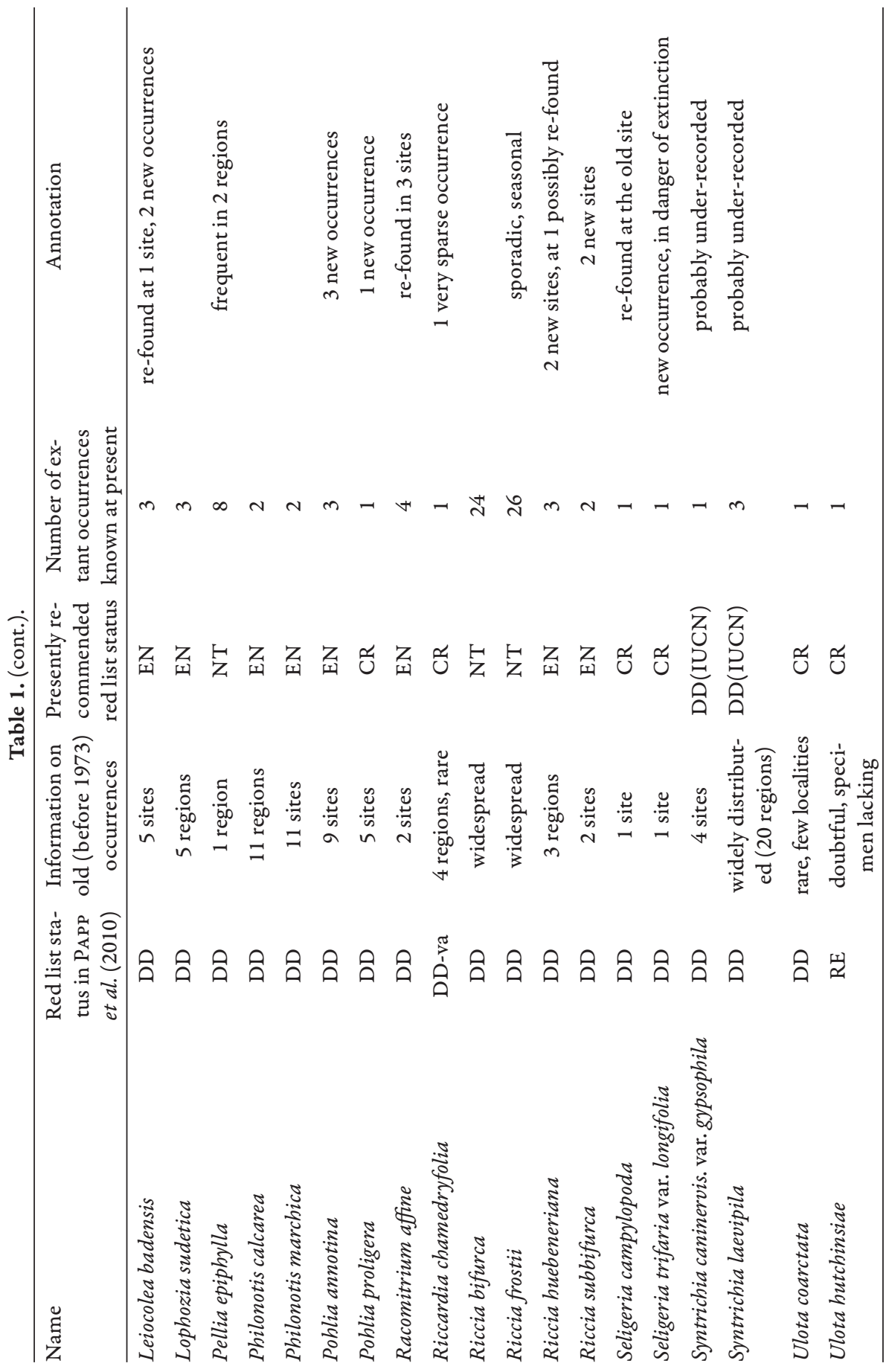


mi revízióknak, már ez alatt a rövid idő alatt is jelentős változások következtek be ismereteinkben, mind a fajszám, mind pedig a vörös listás besorolások tekintetében. A recens terepi kutatások során felgyülemlett jelentős adatmennyiség miatt a változások aktualizálását egy cikksorozat keretében kívánjuk közreadni, melynek első részében a regionálisan kipusztult (RE) és az adathiányos (DD, DDva) fajok kerülnek megvitatásra. A tárgyalt $37 \mathrm{RE}, \mathrm{DD}$ vagy $\mathrm{DD}$-va besorolású taxon közül az újonnan előkerült populációk tükrében 10 a kipusztulással veszélyeztetett (CR: Brachythecium geheebii, Bryum funckii, Fontinalis hypnoides, Jungermannia atrovirens, Pohlia proligera, Riccardia chamedryfolia, Seligeria campylopoda, S. trifaria var. longifolia, Ulota coarctata, U. hutchinsiae), 14 a veszélyeztetett (EN: Bryum creberrimum, B. gemmilucens, B. mildeanum, B. pallescens, B. turbinatum, Campylopus pyriformis, Leiocolea badensis, Lophozia sudetica, Philonotis calcarea, P. marchica, Pohlia annotina, Racomitrium affine, Riccia huebeneriana, R. subbifurca), 2 a sebezhetö (VU: Fossombronia wondraczekii, Isopterygiopsis pulchella), 5 pedig a veszélyeztetettség közeli (NT: Conardia compacta, Fissidens gymnandrus, Pellia epiphylla, Riccia bifurca, R. frostii) kategóriába került át. 6 taxon esetében azonban (Brachythecium capillaceum, Bryum intermedium, Cephaloziella hampeana, Cinclidotus danubicus, Syntrichia caninervis var. gypsophila, S. laevipila) - habár az elmúlt időszakban új előfordulásaik váltak ismertté - mégsem rendelkezünk kellő mennyiségü információval valódi elterjedésük és veszélyeztetettségi státuszuk megítéléséhez. Ezek besorolására a DD(IUCN) kategóriát használtuk.

\section{REFERENCES}

Boros, Á. (1953): Magyarország mohái. - Akadémiai Kiadó, Budapest, 360 pp.

Boros, Á. (1968): Bryogeographie und Bryoflora Ungarns. - Akadémiai Kiadó, Budapest, 466 pp.

Csiky, J., Erzberger, P., Kovács, D. and Deme, J. (2014): Campylopus pyriformis (Schultz) Brid. in the Western Mecsek Mts (South Transdanubia, Hungary). (Campylopus pyriformis (Schultz) Brid. a Ny-Mecsekben). - Kitaibelia 19(2): 366-367.

Damsholt, K. (2002): Illustrated flora of Nordic liverworts and hornworts. - Nordic Bryological Society, Lund, $837 \mathrm{pp}$.

ECCB (1995): Red data book of European bryophytes. - European Committee for Conservation of Bryophytes, Trondheim, $291 \mathrm{pp}$.

Erzberger, P. (2005): The bulbilliferous species of Pohlia (Bryaceae, Musci) in Hungary. - Studia bot. hung. 36: 67-75.

Erzberger, P. (2012): Project plan: bryophyte mapping of Hungary. - Programm and Abstracts, 8th Conference of European Committee for Conservation of Bryophytes, Budapest, 18-21 April 2012, p. 12.

ERzberger, P. and NÉMeth, Cs. (2013): Mohatérképezés Magyarországon - eredmények az iniciális fázisból. [Bryophyte mapping in Hungary - results from the initial phase]. - Absztraktkötet, II. Aktuális eredmények a kriptogám növények kutatásában konferencia, Eger, p. 13.

Erzberger, P. and PAPp, B. (2004): Annotated checklist of Hungarian bryophytes. - Studia bot. hung. 35: 91-149.

ERZberger, P. and Schröder, W. (2008): The genus Schistidium (Grimmiaceae, Musci) in Hungary. - Studia bot. hung. 39: 27-88.

ERzBerger, P. and SchröDer, W. (2013): The genus Bryum (Bryaceae, Musci) in Hungary. Studia bot. hung. 44: 5-192.

Gos, L. and OchYRA, R. (1994): New or otherwise interesting distributional data for species of Seligeria (Musci, Seligeriaceae) for Eurasia. - Fragm. Flor. Geobot. 39: 383-389.

Hallingbäck, T., Hodgetts, N., Raeymaekers, G., Schumacker, R., Sérgio, C., SöderStröm, L., Stewart, N. and VÁNA, J. (1998): Guidelines for application of the revised IUCN threat categories to bryophytes. - Lindbergia 23: 6-12. 
Hill, M. O., Bell, N., Bruggeman-Nannenga, M. A., Brugués, M., Cano, M. J., Enroth, J., Flatberg, K. I., Frahm, J.-P., Gallego, M. T., Garilleti, R., Guerra, J., Hedenäs, L., Holyoak, D. T., Hyvönen, J., Ignatov, M. S., Lara, F., Mazimpaka, V., Muñoz, J. and Söderström, L. (2006): An annotated checklist of the mosses of Europe and Macaronesia. -J. Bryol. 28: 198-267. http://dx.doi.org/10.1179/174328206X119998

Hodgetts, N. G. (2015): Checklist and country status of European bryophytes - towards a new Red List for Europe. - Irish Wildlife Manuals 84: 1-125.

IUCN (2014): Guidelines for using the IUCN red list categories and criteria. Version 11. Prepared by the standards and petitions subcommittee. - http://www.iucnredlist.org/documents/ RedListGuidelines.pdf (accessed: 23.11.2015).

Jovet-Ast, S. (1986): Les Riccia de la région méditerranée. - Cryptogamie Bryol. Lichénol. 7 (Suppl. 3): $287-431$.

Latzel, A. (1934): Beitrag zur Kenntnis der Moose des Komitates Baranya. - Magyar Bot. Lapok 33: $160-191$.

MeINUNGer, L. and SCHRöDer, W. (2007): Verbreitungsatlas der Moose Deutschlands Band 1. - O. Dürhammer für die Regensburgische Botanische Gesellschaft, Regensburg, 636 pp.

Mesterházy, A. and Németh, Cs. (2015): Bruchia flexuosa (Schwägr.) Müll. Hal. [Hungary]. In: Ellis, L. T. (ed.): New national and regional bryophyte records, 45. - J. Bryol. 37(4): (in press)

MK (2012) : A vidékfejlesztési miniszter 100/2012. (IX. 28.) VM rendelete a védett és a fokozottan védett növény- és állatfajokról, a fokozottan védett barlangok köréről, valamint az Európai Közösségben természetvédelmi szempontból jelentős növény- és állatfajok közzétételéről szóló 13/2001. (V. 9.) KöM rendelet és a növényvédelmi tevékenységről szóló 43/2010. (IV. 23.) FVM rendelet módosításáról. [ministerial order concerning protection of nature]. - Magyar Közlöny 128: 20903-21019.

Németh, Cs. (2011): Bryofloristical data from the Transdanubian Mountain Ranges, Bakony and Vértes Mts (Hungary). - Studia bot. hung. 42: 5-22.

Orbán, S. and VAjDa, L. (1983): Magyarország mohaflórájának kézikönyve. [Handbook of the Hungarian bryoflora]. - Akadémiai Kiadó, Budapest, 518 pp.

PApp, B., Erzberger, P., Ódor, P., Hock, Zs., Szövényi, P., SzUrdoki, E. and Tóth, Z. (2010): Updated checklist and red list of Hungarian bryophytes. - Studia bot. hung. 41: 31-59.

Paton, J. A. (1999): The liverwort flora of the British Isles. - Harley Books, Great Horkesley, 626 pp. RajCzy, M. (1990): Mohák - Bryophyta. - In: Ra KonCzay, Z. (ed.): Vörös Könyv. Akadémiai Kiadó, Budapest, pp. 322-325.

Tótн, Z. (1986): A Tortula Hedw. Sect. Rurales De Not. (Musci, Pottiaceae) Rendszertani revíziója és elterjedése a Kárpát-Medencében. (Taxonomic revision of Tortula Hedw. sect. Rurales De Not. (Musci, Pottiaceae) and its distribution in the Carpathian Basin). - Abstracta Botanica 10: $145-185$.

Tótн, Z. (1987): A phytogeographic review of Tortula Hedw. Sect. Rurales De Not. (Pottiaceae, Musci) in Hungary. - Acta Bot. Hung. 33: 249-278.

(submitted: 25.08.2015, accepted: 30.10.2015) 